\title{
Role of Resveratrol and Selenium on Oxidative Stress and Expression of Antioxidant and Anti-Aging Genes in Immortalized Lymphocytes from Alzheimer's Disease Patients
}

\author{
Marta Cosín-Tomàs ${ }^{1,2}$, Júlia Senserrich ${ }^{1}$, Marta Arumí-Planas ${ }^{1}$, Carolina Alquézar ${ }^{3}$, \\ Mercè Pallàs 4,5 (D) Ángeles Martín-Requero ${ }^{3,5}{ }^{(\mathbb{D}}$, Cristina Suñol ${ }^{1,6,7}$, Perla Kaliman ${ }^{1,8}$ and \\ Coral Sanfeliu $1,6,7, *$ \\ 1 Institut d'Investigacions Biomèdiques de Barcelona (IIBB), Consejo Superior de Investigaciones \\ Científicas (CSIC), 08036 Barcelona, Spain \\ 2 Department of Human Genetics, Research Institute of the McGill University Health Centre, \\ Montreal, QC H3A 0C7, Canada \\ 3 Department of Molecular Biomedicine, Centro de Investigaciones Biológicas, CSIC, 28040 Madrid, Spain \\ 4 Faculty of Pharmacy and Food Sciences, Institut de Neurociències, Universitat de Barcelona, \\ 08028 Barcelona, Spain \\ 5 CIBER de Enfermedades Neurodegenerativas (CIBERNED), Instituto de Salud Carlos III, \\ 28031 Madrid, Spain \\ 6 CIBER de Epidemiología y Salud Pública (CIBERESP), Instituto de Salud Carlos III, 28031 Madrid, Spain \\ 7 Institut d'Investigació Biomèdica August Pi i Sunyer (IDIBAPS), 08036 Barcelona, Spain \\ 8 Faculty of Health Sciences, Universitat Oberta de Catalunya, 08018 Barcelona, Spain \\ * Correspondence: coral.sanfeliu@iibb.csic.es; Tel.: +34-933-638-338
}

Received: 26 June 2019; Accepted: 28 July 2019; Published: 31 July 2019

check for updates

\begin{abstract}
Oxidative damage is involved in the pathophysiology of age-related ailments, including Alzheimer's disease (AD). Studies have shown that the brain tissue and also lymphocytes from $\mathrm{AD}$ patients present increased oxidative stress compared to healthy controls (HCs). Here, we use lymphoblastoid cell lines (LCLs) from AD patients and HCs to investigate the role of resveratrol (RV) and selenium (Se) in the reduction of reactive oxygen species (ROS) generated after an oxidative injury. We also studied whether these compounds elicited expression changes in genes involved in the antioxidant cell response and other aging-related mechanisms. AD LCLs showed higher ROS levels than those from $\mathrm{HCs}$ in response to $\mathrm{H}_{2} \mathrm{O}_{2}$ and $\mathrm{FeSO}_{4}$ oxidative insults. $\mathrm{RV}$ triggered a protective response against ROS under control and oxidizing conditions, whereas Se exerted antioxidant effects only in AD LCLs under oxidizing conditions. RV increased the expression of genes encoding known antioxidants (catalase, copper chaperone for superoxide dismutase 1, glutathione S-transferase zeta 1) and anti-aging factors (sirtuin 1 and sirtuin 3) in both AD and HC LCLs. Our findings support RV as a candidate for inducing resilience and protection against $\mathrm{AD}$, and reinforce the value of LCLs as a feasible peripheral cell model for understanding the protective mechanisms of nutraceuticals against oxidative stress in aging and AD.
\end{abstract}

Keywords: Alzheimer's disease; immortalized B lymphoblastoid cell lines; resveratrol; selenium; oxidative stress; aging; gene expression

\section{Introduction}

Alzheimer's disease (AD) is a neurodegenerative disease which is the main cause of dementia worldwide, and it is currently incurable. It is characterized by a loss of memory and progressive 
cognitive, functional, and behavioral decline that interferes with daily life [1]. It is now well recognized that the pathogenesis begins up to one or two decades before the onset of the clinical symptoms [2]. Therefore, understanding the mechanisms that lead to the progression of the disease is essential to establish an early diagnosis and slow or prevent its progression.

The two hallmarks of AD are the accumulation of extracellular senile plaques formed by amyloid beta $(\mathrm{A} \beta)$ peptides, and the accumulation of hyperphosphorylated tau aggregates that form neurofibrillary tangles (NFTs) inside neurons [3]. In addition to plaques and NFTs, oxidative damage to proteins, nucleic acids, and lipids plays a key role in the pathophysiology of the disease, as in most age-related ailments [4]. It has been reported that $A \beta$ promotes the generation of reactive oxygen species (ROS), either directly or indirectly, by triggering N-methyl-D-aspartate receptor-dependent $\mathrm{Ca}^{2+}$ influxes and leading to mitochondrial dysfunction. However, it has been postulated that $\mathrm{A} \beta$ accumulation may be a consequence of oxidative stress and that $A \beta$ and tau act as antioxidants in $\mathrm{AD}$ (reviewed by Sutherland et al. [5]). Although this issue is still unclear, a wide range of studies have shown that the imbalance between the production of ROS, on the one hand, and antioxidant defenses, on the other, contribute considerably to the pathogenesis and progression of AD [4,6-8]. In fact, considerable attention in $\mathrm{AD}$ research has been focused on identifying compounds capable of scavenging excess ROS.

In particular, resveratrol (RV; trans-3,4', 5 -trihydroxystilbene) and selenium (Se), which are both nutraceuticals with antioxidant properties that can permeate the brain blood barrier, seem to have therapeutic potential as neuroprotective agents $[9,10]$. RV is a polyphenol that is mainly found in some fruits such as blueberries, blackberries and grapes, and also in peanuts. It has been shown that RV mimics the anti-aging and neuroprotective effects of caloric restriction through sirtuin 1 (SIRT1) mechanisms [11]. RV indirectly activates SIRT1 through cAMP signaling that leads to activation of the $5^{\prime}$ AMP-activated protein kinase (AMPK)/SIRT1 pathway [12,13]. Furthermore, both in vitro and in vivo experimental AD studies have suggested that RV activates the SIRT1 pathway as its main neuroprotective mechanism [14-17]. However, RV may partially act through other mechanisms, as demonstrated by in vitro treatments in the presence of the SIRT1 inhibitor sirtinol, where RV neuroprotection was only partially abolished [18]. In this regard, RV has potent antioxidant properties through direct scavenging of ROS. Some clinical trials have shown that resveratrol is safe, well-tolerated, and is capable of decreasing neuroinflammation and modifying some AD biomarkers, such as cerebrospinal fluid $A \beta 40$ and $A \beta 42[19,20]$.

Meanwhile, Se is an essential micronutrient for brain function that plays a critical role in multiple metabolic pathways, including those involved in antioxidant defense in organisms [21]. Se is a component of antioxidant enzymes, such as glutathione peroxidase, and there are a number of other selenoenzymes and selenoproteins. There are two different commonly occurring forms of Se in nature, selenite (Se (IV)) and selenate (Se (VI)), and both have been studied in the context of the prevention of $\mathrm{AD}$ onset and progression. Studies have shown that diets supplemented with these components can play a neuroprotective role in AD experimental models [22-24]. For example, Se (IV) can reduce the amount of $\mathrm{A} \beta$ plaques [23] and Se (VI) may reduce hyperphosphorylation of tau [24]. Studies in humans have found a significant decrease of Se in AD brains or blood cells, compared to controls [25,26]. Therefore, both RV and Se diet supplementation are promising strategies to combat aging and AD.

Given that several peripheral and systemic abnormalities interact with the brain and influence the development and progression of the pathology, it has been suggested that AD may be considered a systemic disease [27]. In fact, many authors have shown that not only do components of the nervous system from $\mathrm{AD}$ patients present increased oxidative stress markers compared to healthy controls (HCs), but so too do lymphocytes [28]. This has prompted some authors to use lymphoblastoid cell lines (LCLs) from AD patients and HCs as a suitable and more feasible model to study the disease in vitro. These human cell lines arise from peripheral B lymphocytes infected in vitro with the Epstein-Barr virus; a process that immortalizes them [29]. Some studies have already shown alterations in the 
cell cycle, proliferative activity and $\mathrm{A} \beta$ processing, as well as higher oxidative stress in $\mathrm{AD}$ than control-derived LCLs [30-39].

Within this context, we use LCLs from AD patients and HCs to investigate the potential role of $\mathrm{RV}$ and both Se (IV) and Se (VI) in the reduction of ROS generated after an oxidative injury. We also examine whether these compounds elicit expression changes in genes involved in the antioxidant cell response and other aging-related mechanisms. We found that AD LCLs showed a lower capacity of response against oxidative injuries than HC LCLs, as expected. Furthermore, RV triggered a protective response against ROS under control and oxidizing conditions and increased the expression of gene coding for known antioxidants and anti-aging factors; whereas Se exerted antioxidant effects only in AD LCLs under oxidizing conditions. Our findings support RV as a powerful compound with preventive and therapeutic properties against redox and aging alterations of $\mathrm{AD}$ and reinforce the value of LCLs as a human cell model for studying the protective mechanisms of nutraceuticals.

\section{Materials and Methods}

\subsection{Cell Lines}

Immortalized lymphocytes from AD patients from the Department of Neurology of the University Hospital Doce de Octubre (Madrid, Spain) and age-matched HCs, were used for this study. AD patients were at a moderate stage of the disease and presented values between 10 and 18 in the Mini-Mental State Examination. Details of the informed consent and technical procedures for the establishment of LCLs from peripheral blood samples were previously reported [32]. The cells were cultured in Roswell Park Memorial Institute (RPMI)-1640 (Biowest, Nuaillé, France, \#L0500), which contained 2 mM L-glutamine, supplemented with 10\% fetal bovine serum (FBS; Gibco, Pailey, Scotland, \#10270) and $1 \%$ penicillin/streptomycin (Gibco, \#15070) or 0.1\% gentamicin (Gibco, \#15750-045). LCLs were grown in suspension inside T25 flasks in an upright position, in $8 \mathrm{~mL}$ of completed medium per flask and at a density of $1 \times 10^{6}$ cells/mL. They were maintained in a humidified $5 \%$ carbon dioxide incubator at $37^{\circ} \mathrm{C}$. The culture medium was routinely changed every 2 days by removing $4 \mathrm{~mL}$ of the medium from above the cells and replacing it with an equal volume of fresh medium. The cell lines were routinely tested for the absence of mycoplasma contamination (Mycoplasma Gel Detection Kit; Biotools, Madrid, Spain, \#4542). For the experiments, cells were seeded in $2 \mathrm{~mL}$ tubes with $1 \mathrm{~mL}$ of medium without FBS for the time required before each experiment at a concentration of $3 \times 10^{5}$ cells $/ \mathrm{mL}$. All the cell culture plastic was from $\mathrm{Nunc}^{\mathrm{TM}}$ (ThermoFisher Scientific, Waltham, MA, USA).

\subsection{Characterization of Oxidative Stress by DCFH-DA (2'7'-dichloro-dihydro-fluorescein diacetate) Assay}

The most widely used probe for the detection of oxidative species in living cells is $2^{\prime} 7^{\prime}$-dichloro-dihydro-fluorescein diacetate (DCFH-DA). It is a non-fluorescent cell-permeable molecule. Within cells, the acetate groups are hydrolyzed by intracellular esterases, leading to $2^{\prime}, 7^{\prime}$-dichloro-dihydro-fluorescein (DCFH). The presence of ROS, mainly hydroperoxides, oxidizes DCFH to dichlorofluorescein (DCF), which is highly fluorescent [40]. To use this technique, cells from 2-3 different AD or HC LCLs were seeded at a cell density of $3 \times 10^{5}$ cells/mL in T25 flasks, the day before the experiment, in FBS-free medium. For the test, the cells were gently homogenized with the medium and $1 \mathrm{~mL}$ was transferred to different tubes. After centrifugation at $1000 \mathrm{rpm}$ for $5 \mathrm{~min}$, the cells were resuspended with $400 \mu \mathrm{L}$ of 4-(2-hydroxyethyl)-1-piperazineethanesulfonic acid (HEPES)-buffered saline solution (HBSS) and $4 \mu \mathrm{L}$ of $100 \times$ DCFH-DA $(10 \mu \mathrm{M}$ final concentration; Molecular Probes, Leiden, The Netherlands, \#D-399) or $4 \mu \mathrm{L}$ of HBSS for the negative controls. Negative controls were used to obtain the background fluorescence data and were processed in parallel throughout the experiment. After suspension, all the samples were incubated for 20 min with gentle shaking at $37^{\circ} \mathrm{C}$ in the dark to allow the DCFH-DA to load into the cells. After centrifugation for $5 \mathrm{~min}$ at $200 \mathrm{rcf}$, the supernatant was removed, and the cells were resuspended in $400 \mu \mathrm{L}$ of HBSS containing the corresponding treatments (performed in triplicates). The different conditions were: 
control treatment with HBSS only, and different concentrations of the oxidizing agents $\mathrm{H}_{2} \mathrm{O}_{2}(200 \mu \mathrm{M}$, $500 \mu \mathrm{M}$, and $1000 \mu \mathrm{M}$; Sigma, St Louis, MO, USA, \#216763) and $\mathrm{FeSO}_{4}(1 \mu \mathrm{M}, 5 \mu \mathrm{M}$, and $25 \mu \mathrm{M}$; Sigma, \#F7002) in HBSS. Then, all the samples were incubated for $1 \mathrm{~h}$ with gentle shaking at $37^{\circ} \mathrm{C}$ in the dark. Next, $44 \mu \mathrm{L}$ of $10 \times$ lysis buffer was added to each tube. All the samples were homogenized and centrifuged at 10,000 $\mathrm{rcf}$ for $10 \mathrm{~min}$, and $200 \mu \mathrm{L}$ of the supernatant was transferred to a 96-well plate, making two replicates per sample. Cell fluorescence was determined using a SPECTRAmax GEMINI XS microplate reader fluorimeter (Molecular Devices, San Jose, CA, USA), with a wavelength of excitation and emission of $485 \mathrm{~nm}$ and $530 \mathrm{~nm}$, respectively. Finally, in order to control for the cellular protein content, $50 \mu \mathrm{L}$ of $2 \mathrm{~N} \mathrm{NaOH}$ solution was added to the cell pellet for future processing using the Bradford protein assay (Bio-Rad Protein Assay Dye Reagent Concentrate; Bio-Rad, Hercules, CA, USA, \#500-0006).

\subsection{DCFH-DA Assay to Study Se (IV), Se (VI,) and RV Antioxidant Effects}

The same protocol as for the DCFH-DA assay described above was applied with some changes. Cells from 2-3 different AD or HC LCLs were seeded at a density of $3 \times 10^{5}$ cells $/ \mathrm{mL}$ in $2 \mathrm{~mL}$ tubes. Twenty $\mu \mathrm{L}$ of each protective treatment was added to the corresponding tubes (performed in triplicate). The concentrations of the protective compounds were obtained from the literature and tested in preliminary studies not to affect cell growth or viability. The different protective treatments were: Se (IV) (Sigma, \#S5261) at 5 and $10 \mu \mathrm{M}$, Se (VI) (Sigma, \#S0882) at 100 and $200 \mu \mathrm{M}$, and RV (Sigma, \#R5010) at 10 and $50 \mu \mathrm{M}$. RV, Se (IV), and Se (VI) were solubilized with DMSO $(0.1 \%)$ or HBSS, respectively. Afterwards, DMSO was added to all the experimental conditions (0.1\%). After overnight incubation (18 h), the samples were centrifuged at $1000 \mathrm{rpm}$ for $5 \mathrm{~min}$; cells were resuspended with $400 \mu \mathrm{L}$ HBSS and $4 \mu \mathrm{L}$ of $100 \times \mathrm{DCFH}-\mathrm{DA}$. Eight $\mu \mathrm{L}$ of each protective treatment was again added to maintain the corresponding concentrations. Then, the samples were incubated for $20 \mathrm{~min}$ with gentle shaking at $37^{\circ} \mathrm{C}$ in the dark. After centrifugation for $5 \mathrm{~min}$ at $200 \mathrm{rcf}$, the supernatant was removed, and the cells were resuspended in $400 \mu \mathrm{L}$ of the corresponding protective treatment and/or the agents used to induce oxidative stress: $\mathrm{H}_{2} \mathrm{O}_{2}$ and $\mathrm{FeSO}_{4}$. The final experimental conditions were: control, $1000 \mu \mathrm{M}$ $\mathrm{H}_{2} \mathrm{O}_{2}$ or $5 \mu \mathrm{M} \mathrm{FeSO}_{4}$, with $8 \mu \mathrm{L}$ of Se (IV), Se (VI), or RV. The samples were incubated for $1 \mathrm{~h}$ with gentle shaking at $37^{\circ} \mathrm{C}$ in the dark. Next, $44 \mu \mathrm{L}$ of lysis buffer $10 \times$ was added to each tube. All the points were homogenized and after centrifugation at 10,000 $\mathrm{rcf}$ for $10 \mathrm{~min}, 200 \mu \mathrm{L}$ of the supernatant was transferred to a 96-well plate, making 2 replicates for each sample. Finally, in order to control the cellular protein content, $50 \mu \mathrm{L}$ of $2 \mathrm{~N} \mathrm{NaOH}$ solution was added to the cell pellet for future processing using the Bradford protein assay.

\subsection{Gene Expression Analysis}

Cells from 2-3 different AD or HC LCLs were transferred to $2 \mathrm{~mL}$ tubes containing FBS-free medium and incubated for $18 \mathrm{~h}$ at a concentration of $3 \times 10^{5}$ cells $/ \mathrm{mL}$ with the corresponding treatment (four replicates per experimental condition). The samples were removed from the incubator and rapidly centrifuged at $1300 \mathrm{rpm}$ for $5 \mathrm{~min}$ and washed with $200 \mu \mathrm{L}$ of PBS. Then, the samples were centrifuged again at the same speed for $5 \mathrm{~min}$, the supernatant was removed, and cells were resuspended with $20 \mu \mathrm{L}$ of PBS followed by $180 \mu \mathrm{L}$ of RNA later (Sigma, \#R0901). The samples were stored at $4{ }^{\circ} \mathrm{C}$. The different experimental conditions consisted of: non-treatment control, Se (IV) at $10 \mu \mathrm{M}$, Se (VI) at $200 \mu \mathrm{M}$, and RV at $50 \mu \mathrm{M}$. RV, Se (IV), and Se (VI) were solubilized with DMSO (0.1\%) and HBSS, respectively. DMSO was added in all experimental conditions. The analysis of gene expression was performed in the absence of oxidative challenges.

\section{5. $m R N A$ Purification}

The four samples corresponding to the same conditions were pooled in one single tube. Then, RNA later was removed, and RNA was extracted using mirVana ${ }^{\mathrm{TM}}$ miRNA Isolation Kits (Life Technologies, Carlsbad, CA, USA, \#AM1561), following the manufacturer's instructions to obtain total 
RNA, including small RNA. The quantity and quality of the RNA samples was determined using a ND-1000 spectrophotometer (NanoDrop Technologies, Wilmington, DE, USA). Samples with low concentrations of RNA were concentrated using the SpeedVac vacuum system (Savant, ThermoFisher, Waltham, MA, USA). Samples were stored at $-80{ }^{\circ} \mathrm{C}$ until further use.

\section{6. cDNA Reverse Transcription}

Random-primed cDNA synthesis was performed at $37^{\circ} \mathrm{C}$ starting with $0.3 \mu \mathrm{g}$ of RNA, using high-capacity cDNA Reverse Transcription Kits (Life Technologies, \#4368814). All the samples were diluted at a $1: 4$ ratio and stored at $-20{ }^{\circ} \mathrm{C}$ until further use.

\subsection{Real-Time Quantitative PCR}

Gene expression of candidate genes was determined using TaqMan Fluorescein amidite (FAM)-labeled specific probes (Applied Biosystems, Foster City, CA, USA) and Quantimix Easy Probe kits (Biotools, \#10.601-4149) in an RFX96TM Real-time system (Bio-Rad). Samples were analyzed in duplicate. Results were normalized to phosphoglycerate kinase 1 (PGK1) and beta-2-microglobulin (B2M) gene expression levels. A list of probes is provided in Supplementary Table S1.

\subsection{Statistical Analysis}

Statistical analysis was performed using GraphPad Prism 5.01 software (GraphPad Software, La Jolla, CA, USA). Analysis was via two-way ANOVA. Significance values were given for the two factors: treatment (Tr) and disease (Ds), and for the interaction $\operatorname{Tr} \times$ Ds. A post hoc Tukey's test, or Fisher's Least Significant Difference (LSD) test, was applied after a significant Tr effect (since this factor has more than two levels) and after a significant interaction. All the values are shown as mean \pm standard error (SEM). Statistical outliers ( $\geq$ two standard deviations from the mean) were removed from the analysis. $P$-values $\leq 0.05$ were considered statistically significant.

\section{Results}

\subsection{Characterization of HC and AD LCLs in Response to Acute Exposure of Oxidizing Agents}

Intracellular ROS formation in HC and AD LCLs after $1 \mathrm{~h}$ exposure to different concentrations of the oxidizing agents $\mathrm{H}_{2} \mathrm{O}_{2}(200 \mu \mathrm{M}, 500 \mu \mathrm{M}$, and $1000 \mu \mathrm{M})$ and $\mathrm{FeSO}_{4}(1 \mu \mathrm{M}, 5 \mu \mathrm{M}$, and $25 \mu \mathrm{M})$ was measured by the DCFH-DA assay. Higher concentrations of $\mathrm{H}_{2} \mathrm{O}_{2}$ produced more oxidative stress than lower doses $(\mathrm{Tr}, \mathrm{F}(3,16)=19.52, p<0.0001)$ (Figure 1a). Notably, there was a significantly higher ROS production in AD than in HC lymphoblasts (Ds, $\mathrm{F}(1,16)=17.21, p<0.0001)$ (Figure 1a). Treatment with $\mathrm{H}_{2} \mathrm{O}_{2}$ became significant at $500 \mu \mathrm{M}$ and $1000 \mu \mathrm{M} \mathrm{H}_{2} \mathrm{O}_{2}$ in $\mathrm{AD}$ and $\mathrm{HC}$ lymphoblasts, respectively, indicating that $\mathrm{AD}$ lymphoblasts are more sensitive to oxidative stress insults (Tukey's post hoc tests, control vs. $500 \mu \mathrm{M} \mathrm{H}_{2} \mathrm{O}_{2}$ : $\mathrm{HC} p=$ ns, $\mathrm{AD} p<0.01$; control vs. $1000 \mu \mathrm{M} \mathrm{H}_{2} \mathrm{O}_{2}: \mathrm{HC} p<0.01, \mathrm{AD}$ $p<0.0001)$.

Exposure to higher concentrations of $\mathrm{FeSO}_{4}$ triggered an increase in the production of ROS in both groups ( $\operatorname{Tr}, \mathrm{F}(3,16)=122.2, p<0.0001)$ (Figure $1 \mathrm{~b}$ ). However, it is important to note that with the highest concentration of $\mathrm{FeSO}_{4}$ used $(25 \mu \mathrm{M})$, ROS levels did not further increase but were rather lower than with the $1 \mu \mathrm{M}$ and $5 \mu \mathrm{M}$ doses, which suggests that this concentration is too high for increasing the metabolic response to a higher ROS production in these particular cell lines. As with $\mathrm{H}_{2} \mathrm{O}_{2}$, there was a significantly higher ROS production in $\mathrm{AD}$ than in HC lymphoblasts $(\mathrm{Ds}, \mathrm{F}(1,16)=13.23, p<0.01$ ) (Figure 1b).

Therefore, AD LCLs showed higher ROS generation than HC LCLs after both peroxide-induced and iron-catalyzed oxidative injuries. 
a)

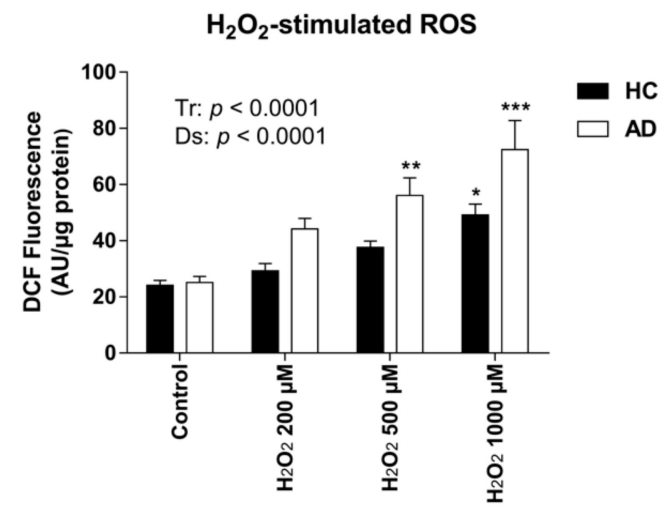

b)

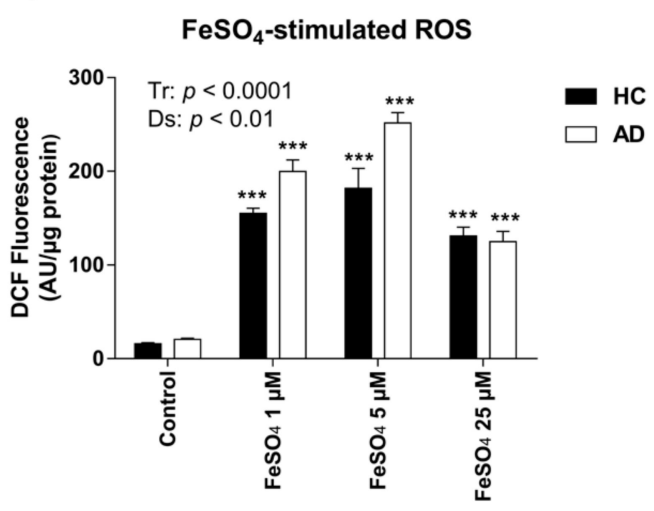

Figure 1. Reactive oxygen species (ROS) generation by lymphoblast cell lines in response to acute exposure $(1 \mathrm{~h})$ to oxidizing agents measured by $2^{\prime} 7^{\prime}$-dichloro-dihydro-fluorescein diacetate (DCFH-DA) assay. (a) $\mathrm{H}_{2} \mathrm{O}_{2}$-stimulated ROS. One h of treatment with $\mathrm{H}_{2} \mathrm{O}_{2}$ induced oxidative stress, showing significant greater ROS generation in Alzheimer's disease (AD) than in healthy control (HC) lymphoblasts. Two-way ANOVA indicated an effect of both treatment $(\operatorname{Tr})(\mathrm{F}(3,16)=19.52 ; p<0.0001)$ and disease $(\mathrm{Ds})(\mathrm{F}(1,16)=17.21 ; p<0.001) ;(\mathbf{b}) \mathrm{FeSO}_{4}$-stimulated $\mathrm{ROS}$. $\mathrm{FeSO}_{4}$ induced oxidative stress. Two-way ANOVA indicated effects of both $\operatorname{Tr}(\mathrm{F}(3,16)=122.2$ and $p<0.0001)$ and $\mathrm{Ds}(\mathrm{F}(1,16)=13.23$; $p<0.01)$; and an interaction $\operatorname{Tr} \times \operatorname{Ds}(\mathrm{F}(3,16)=5.121 ; p<0.05)$. Values are mean $\pm \mathrm{SEM}$ of three independent experiments with $n=3-5 /$ experiments on two different cell lines per group. $P$-values of Tukey's post hoc tests for each experimental condition relative to the control treatment within each group (AD or HC) are presented as: ${ }^{*} p<0.05,{ }^{* *} p<0.01$, and ${ }^{* *} p<0.001$.

\subsection{Protective Effect of RV and Se against ROS Production in HC and AD LCLS}

In order to explore the protective action of RV, Se (IV), and Se (VI) treatments on oxidative stress, DCFH-DA assays were conducted in both HC and AD LCLs. Two different concentrations of each compound were used as follows: $5 \mu \mathrm{M}$ and $10 \mu \mathrm{M}$ Se (IV), $100 \mu \mathrm{M}$ and $200 \mu \mathrm{M}$ Se (VI), and $10 \mu \mathrm{M}$ and $50 \mu \mathrm{M}$ RV. All the concentrations were into the range of those used in a number of previously reported in vitro studies. Specifically, we selected the highest effective concentrations that did not inhibit viability and cell growth in human lymphocytes [41-44]. Compounds were incubated overnight $(18 \mathrm{~h})$ and immediately tested for their effects on inhibiting ROS generation for a further $1 \mathrm{~h}$ under control (vehicle) and oxidizing conditions (1000 $\mu \mathrm{M} \mathrm{H}_{2} \mathrm{O}_{2}$ and $\left.5 \mu \mathrm{M} \mathrm{FeSO}_{4}\right)$.

Two-way ANOVA analysis indicated a Tr and Ds factor effect when the DCFH-DA assay was conducted with Se (IV), Se (VI), and RV in control conditions ( $\mathrm{Tr}, \mathrm{F}(6,57)=26.95 ; p<0.0001 ; \mathrm{Ds}, \mathrm{F}(1,57)$ $=9.056 ; p<0.01$ ) (Figure 2a). Particularly, the decrease in ROS was significantly triggered by RV according to Tukey's post hoc tests (HC: control vs. 10 or $50 \mu \mathrm{M} \mathrm{RV,} p<0.0001$; AD: control vs. $10 \mu \mathrm{M}$ $\mathrm{RV}, p<0.001$, control vs. $50 \mu \mathrm{M}$ RV, $p<0.0001$ ) (Figure 2a).

Similarly, under oxidizing conditions triggered by both $\mathrm{H}_{2} \mathrm{O}_{2}$ and $\mathrm{FeSO}_{4}$, there was a general $\mathrm{Tr}$ and Ds effect, according to two-way ANOVA analysis for $\mathrm{H}_{2} \mathrm{O}_{2}(\mathrm{Tr}, \mathrm{F}(6,57)=21.07 ; p<0.0001$; Ds, $\mathrm{F}(1,57)=23.68 ; p<0.0001)$ and $\mathrm{FeSO}_{4}(\mathrm{Tr}, \mathrm{F}(6,57)=48.69 ; p<0.0001 ; \mathrm{Ds}, \mathrm{F}(1,57)=22.86 ; p<0.0001)$ (Figure 2b,c).

Interestingly, in the case of $\mathrm{H}_{2} \mathrm{O}_{2}$ cell culture experiment, $\mathrm{RV}$ was the only treatment that lowered ROS production in the HC LCLs, whereas Se (IV), Se (VI), and RV treatments were protective for AD LCLs (HC: control vs. $10 \mu \mathrm{M}$ RV, $p<0.001$, control vs. $50 \mu \mathrm{M}$ RV, $p<0.0001$; AD: control vs. $10 \mu \mathrm{M}$ Se (IV), $100 \mu \mathrm{M}$ Se (VI), $10 \mu \mathrm{M}$ RV, and $50 \mu \mathrm{M}$ RV, all $p<0.01$ ) (Figure 2b). Regarding differences between $\mathrm{HC}$ and $\mathrm{AD}$ groups at the same experimental condition, Tukey's post hoc tests indicated higher ROS levels in AD LCLs compared to HC LCLs under $\mathrm{H}_{2} \mathrm{O}_{2}$ alone and under $\mathrm{H}_{2} \mathrm{O}_{2}$ plus $10 \mu \mathrm{MV}$ treatment (control: HC vs. AD, $p<0.01 ; 10 \mu \mathrm{M}$ RV treatment: HC vs. AD, $p<0.05$ ) (Figure 2b). 
Notably, in the case of lymphoblasts exposed to $\mathrm{FeSO}_{4}$, there was a significant interaction $\mathrm{Tr} \times \mathrm{Ds}$ $(\mathrm{F}(6,57)=11.74 ; p<0.0001)$ (Figure 2c). As in the case of $\mathrm{H}_{2} \mathrm{O}_{2}, \mathrm{RV}$ triggered a reduction of ROS in the HC LCLs (control vs. 10 or $50 \mu \mathrm{M}$ RV, $p<0.0001$ ), whereas all treatments significantly decreased ROS production in AD LCLs (AD: control vs. 5 or $10 \mu \mathrm{M}$ Se (IV), 100 or $200 \mu \mathrm{M}$ Se (VI), 10 or $50 \mu \mathrm{M}$ RV, $p<0.0001$ ) (Figure 2c).

a)

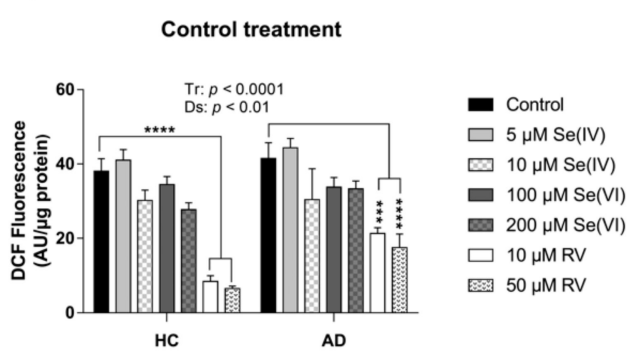

b)

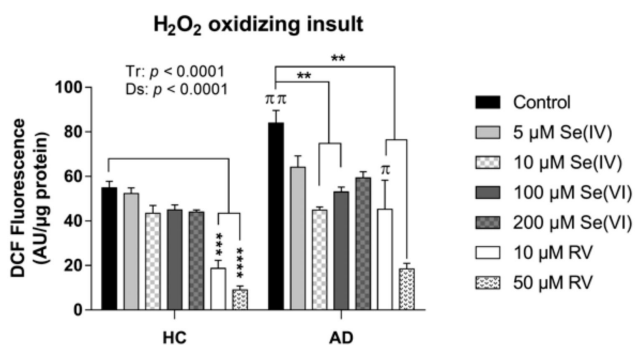

c)

$\mathrm{FeSO}_{4}$ oxidizing insult

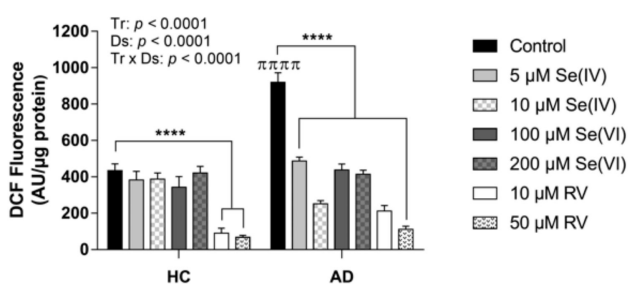

Figure 2. Intracellular ROS after $18 \mathrm{~h}$ of exposure to selenite (Se (IV)), selenate (Se (VI)), and resveratrol (RV) measured by DCFH-DA assay in HC and AD lymphoblasts cell lines. (a) DCFH-DA assay with Se (IV), Se (VI), and RV treatments in combination with the vehicle. Two-way ANOVA indicated overall treatment $(\mathrm{Tr})$ and sisease (Ds) effects: $(\mathrm{F}(6,57)=26.95 ; p<0.0001)$ and $(\mathrm{F}(1,57)=9.056 ; p<0.01)$, respectively; (b) DCFH-DA assay with Se (IV), Se (VI), and RV treatments in combination with $\mathrm{H}_{2} \mathrm{O}_{2}$. Two-way ANOVA indicated overall Tr and Ds effects: $(\mathrm{F}(6,57)=21.07 ; p<0.0001)$ and $(\mathrm{F}(1,57)=23.68$; $p<0.0001$ ), respectively; (c) DCFH-DA assay with Se (IV), Se (VI), and RV treatments in combination with $\mathrm{FeSO}_{4}$. Two-way ANOVA indicated overall Tr and Ds effects, as well as an interaction $\mathrm{Tr} \times \mathrm{Ds}$ : $(\mathrm{F}(6,57)=48.69 ; p<0.0001),(\mathrm{F}(1,57)=22.86 ; p<0.0001)$, and $(\mathrm{F}(6,57)=11.74 ; p<0.0001)$, respectively. Values are mean \pm SEM of six independent experiments with $n=2 /$ experiment on two different cell lines per group. HC and AD stand for healthy control and Alzheimer's disease, respectively. $P$-values of Tukey's post hoc tests are presented as: ${ }^{* *} p<0.01{ }^{* * *} p<0.001$, and ${ }^{* * * *} p<0.001$ for comparisons between treatments within each group (HC or AD); and as: $\pi p<0.05, \pi \pi p<0.01$, and $\pi \pi \pi \pi p<0.001$, for comparisons between groups within each experimental condition.

Overall, RV triggered a general protective response against ROS under both control and oxidizing conditions whereas Se exerted antioxidant effects only in AD cell lines under oxidizing conditions. AD LCLs showed higher ROS levels than HC LCLs in the presence of oxidative agents, which is consistent with results from the first experiments described above. Although we observed a consistent protective effect of RV and Se against oxidative stress, additional characterization would be required to confirm the absence of harmful effects of these compounds on other cellular pathways when administered in combination with oxidative agents (i.e., $\mathrm{H}_{2} \mathrm{O}_{2}$ or $\mathrm{FeSO}_{4}$ ).

3.3. Transcriptional Changes in Oxidative Stress-Related Genes Induced by Se (IV), Se (VI), and RV in HC and AD LCLS

Lower levels of antioxidant enzymes and other first-line endogenous defenses against oxidative stress have been reported in $\mathrm{AD}[4,6]$. Furthermore, according to several studies of animals and other 
in vitro models, $\mathrm{RV}$ and Se can induce an antioxidant response by triggering transcriptional changes in genes involved in the cellular antioxidant system [45,46]. In order to study these particular mechanisms in our model, we incubated HC and AD LCLs for $18 \mathrm{~h}$ with either the vehicle alone or the highest concentration previously tested against oxidative injury, namely $10 \mu \mathrm{M}$ Se (IV), $200 \mu \mathrm{M}$ Se (VI), and $50 \mu \mathrm{M}$ RV. We then measured the mRNA levels of a battery of genes known to be involved in oxidative stress processes (Table 1, Supplementary Table S1).

Two-way ANOVA revealed that catalase (CAT), glutathione S-transferase zeta 1 (GSTZ1), nuclear factor (erythroid-derived 2)-like 2 (NFE2L2), superoxide dismutase 2 (SOD2), and thioredoxin interacting protein (TXNIP) were upregulated due to the treatments (Table 1, Figure 3a,g-j). Particularly, RV significantly increased CAT, NFE2L2, and SOD2 in both HC and AD LCLs, whereas the change in expression of GSTZ1 and TXNIP did not reach significance according to Tukey's post hoc tests (CAT: HC or AD control vs. HC or AD RV $p<0.0001$; NFE2L2: HC or AD control vs. HC or AD RV $p<0.01$; SOD2: HC control vs. HC RV $p<0.05$, AD control vs. AD RV $p<0.01$ ). In the case of copper chaperone for SOD1 (CCS) and glutathione peroxidase 4 (GPX4), there was a tendency towards upregulation by treatment according to two-way ANOVA (Table 1, Figure 3b,e).

Meanwhile, we observed a global decrease in gene expression of CCS, GSTZ1, and TXNIP in AD lymphoblasts compared to HC LCLs, according to two-way ANOVA analysis (Table 1, Figure 3b,g,k). No interactions between treatment and disease were detected for any of the genes studied.

As a whole, the treatment with RV demonstrated the capacity to induce several antioxidant and ROS detoxifying genes in HC and AD LCLs, whereas the effects of Se were minor and not statistically significant. Furthermore, AD LCL antioxidant defenses seemed impaired according to the lower expression of some of the genes in comparison to HC LCLs. 
Table 1. Two-way ANOVA analysis of relative expression of genes involved in oxidative stress in AD and HC lymphoblasts treated with selenite (Se (IV)), selenate (Se $(\mathrm{VI})$ ), and resveratrol (RV).

\begin{tabular}{|c|c|c|c|c|c|c|c|c|c|c|c|c|}
\hline \multirow{2}{*}{ Gene Name } & \multirow{2}{*}{ Association with Oxidative Stress } & \multirow{2}{*}{ Ref } & \multirow{2}{*}{$\begin{array}{l}\text { Gene } \\
\text { Symbol }\end{array}$} & \multicolumn{3}{|c|}{ Interaction } & \multicolumn{3}{|c|}{ Treatment Effect } & \multicolumn{3}{|c|}{ Disease Effect } \\
\hline & & & & F & (Dfn, DFd) & $p$-Value & $\mathbf{F}$ & (Dfn, DFd) & $p$-Value & $\mathrm{F}$ & (Dfn, DFd) & $p$-Value \\
\hline Catalase & $\begin{array}{l}\text { Catalase is an enzyme that protects aerobic cells from oxidative stress by catalyzing the rapid } \\
\text { decomposition of hydrogen peroxide. }\end{array}$ & [47] & $C A T$ & 0.368 & $(3,12)$ & 0.7775 & 59.07 & $(3,12)$ & $<0.0001$ & 0.00215 & $(1,12)$ & 0.9638 \\
\hline $\begin{array}{l}\text { Copper chaperone } \\
\quad \text { for SOD1 }\end{array}$ & $\begin{array}{l}\text { CCS is involved in physiological SOD1 activation (one of the three superoxide dismutases } \\
\text { responsible for metabolizing free superoxide radicals in the body), and its primary function is } \\
\text { thought to be the delivery of copper to the enzyme. }\end{array}$ & [48] & CCS & 0.3915 & $(3,11)$ & 0.7616 & 3.52 & $(3,11)$ & 0.0524 & 7.828 & $(1,11)$ & 0.0173 \\
\hline Alpha-galactosidase & $\begin{array}{l}\text { GLA is an enzyme that hydrolyses the terminal alpha-galactosyl moieties from glycolipids } \\
\text { and glycoproteins. Insufficient activity of GLA leads to accumulation of ROS. }\end{array}$ & [49] & GLA & 0.0085 & $(3,11)$ & 0.9988 & 0.6197 & $(3,11)$ & 0.6167 & 3.679 & $(1,11)$ & 0.0814 \\
\hline $\begin{array}{l}\text { Glutathione } \\
\text { peroxidase } 1\end{array}$ & \multirow{2}{*}{$\begin{array}{l}\text { Glutathione peroxidase (GPX) is a class of antioxidant enzymes that catalyze the reduction of } \\
\text { hydrogen peroxide to water. GPX1 overexpression is associated with enhanced protection } \\
\text { against oxidative stress. GPX4 is the only glutathione peroxidase that accepts phospholipid } \\
\text { hydroperoxides in membranes as an oxidizing substrate, and under conditions of glutathione } \\
\text { deprivation, protein-thiol groups as the reducing substrate. }\end{array}$} & [50] & GPX1 & 0.3812 & $(3,12)$ & 0.7684 & 1.062 & $(3,12)$ & 0.4014 & 4.048 & $(1,12)$ & 0.0672 \\
\hline $\begin{array}{l}\text { Glutathione } \\
\text { peroxidase } 4\end{array}$ & & [51] & GPX4 & 0.99 & $(3,12)$ & 0.4304 & 2.928 & $(3,12)$ & 0.0770 & 2.928 & $(1,12)$ & 0.1128 \\
\hline $\begin{array}{l}\text { Glutathione } \\
\text { reductase }\end{array}$ & $\begin{array}{l}\text { GSR is an enzyme involved in the glutathione-dependent antioxidant system by reducing } \\
\text { oxidized glutathione. }\end{array}$ & [52] & GSR & 0.0076 & $(3,11)$ & 0.9990 & 0.953 & $(3,11)$ & 0.4487 & 1.935 & $(1,11)$ & 0.1917 \\
\hline $\begin{array}{c}\text { Glutathione } \\
\text { S-transferase zeta } 1\end{array}$ & $\begin{array}{l}\text { GSTZ1 catalyzes glutathione-dependent isomerization of maleylacetoacetate to } \\
\text { fumarylacetoacetate, which is the second-to-last step in the vital phenylalanine and tyrosine } \\
\text { degradation pathway. Deficiency of this enzyme causes oxidative stress and activation of } \\
\text { antioxidant response pathways. }\end{array}$ & [53] & GSTZ1 & 0.7762 & $(3,11)$ & 0.5313 & 10.16 & $(3,11)$ & 0.0017 & 6.139 & $(1,11)$ & 0.0307 \\
\hline $\begin{array}{l}\text { Nuclear factor } \\
\text { (erythroid-derived } \\
\text { 2)-like } 2\end{array}$ & $\begin{array}{l}\text { NFE2L2 is a transcription factor involved in the intracellular antioxidant machinery. This } \\
\text { enzyme transactivates genes with antioxidant response elements (AREs), and it coordinates } \\
\text { the expression of cytoprotective genes to counteract endogenously or exogenously generated } \\
\text { oxidative stress }\end{array}$ & [54] & NFE2L2 & 0.05632 & $(3,12)$ & 0.9816 & 15.56 & $(3,12)$ & 0.0002 & 0.2812 & $(1,12)$ & 0.6056 \\
\hline Peroxiredoxin 5 & $\begin{array}{l}\text { PRDX5 is a novel thioredoxin peroxidase which directly promotes the elimination of } \\
\text { hydrogen peroxide and neutralization of other reactive oxygen species. }\end{array}$ & [55] & PRDX5 & 0.5956 & $(3,11)$ & 0.6309 & 1.719 & $(3,11)$ & 0.2206 & 4.015 & $(1,11)$ & 0.0704 \\
\hline $\begin{array}{l}\text { Superoxide } \\
\text { dismutase } 2\end{array}$ & $\begin{array}{l}\text { This gene is a member of the iron/manganese superoxide dismutase family. It encodes an } \\
\text { antioxidant mitochondrial protein that binds to the superoxide byproducts of oxidative } \\
\text { phosphorylation and converts them to hydrogen peroxide and diatomic oxygen. }\end{array}$ & [56] & SOD2 & 0.09583 & $(3,12)$ & 0.9609 & 14.93 & $(3,12)$ & 0.0002 & 0.6395 & $(1,12)$ & 0.4394 \\
\hline $\begin{array}{l}\text { Thioredoxin } \\
\text { interacting protein }\end{array}$ & $\begin{array}{l}\text { TXNIP is a negative regulator of TRX, which plays a major role in maintaining the redox } \\
\text { status. It is upregulated with aging; its overexpression shortens lifespan due to elevated } \\
\text { oxidative DNA damage, whereas its downregulation enhances oxidative stress resistance and } \\
\text { extends lifespan. }\end{array}$ & [57] & TXNIP & 0.3262 & $(3,11)$ & 0.8065 & 3.863 & $(3,11)$ & 0.0413 & 7.142 & $(1,11)$ & 0.0217 \\
\hline
\end{tabular}

$p$-values $<0.05$ were considered statistically significant. DF stands for degrees of freedom. Bold and italic values correspond to statistically significant $p$-values and $p$-values $<0.1$, respectively. 
a)

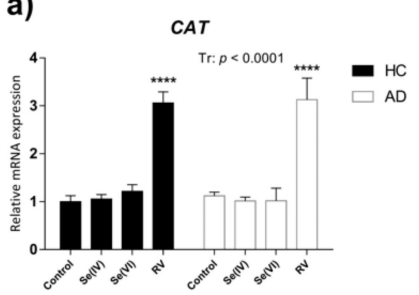

d)

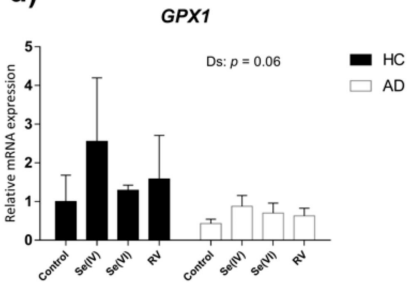

g)

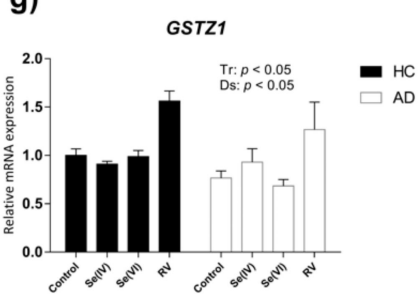

j)

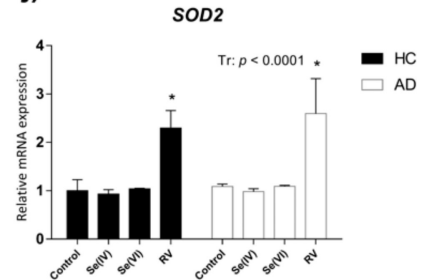

b)

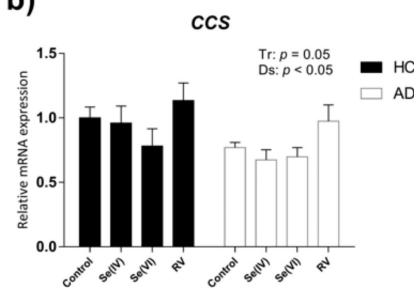

e)

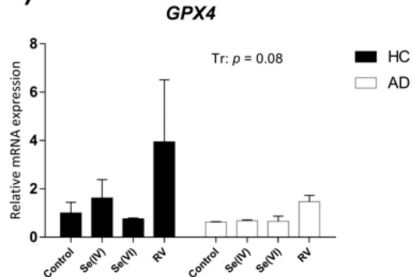

h)

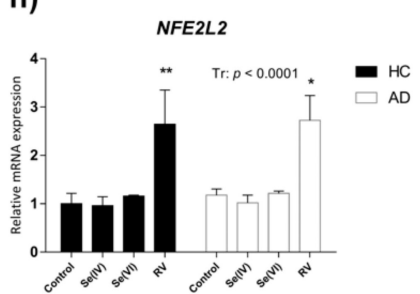

k)

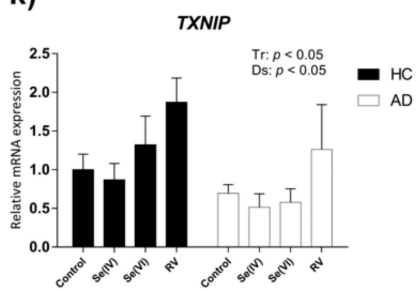

c)

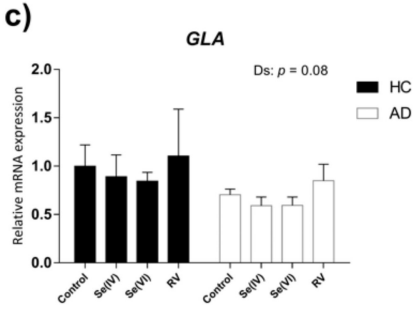

f)

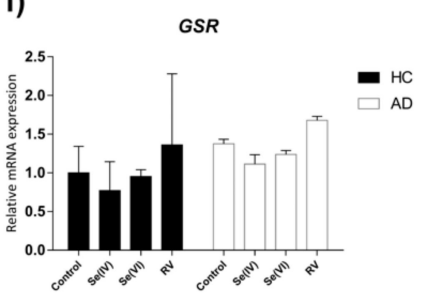

i)

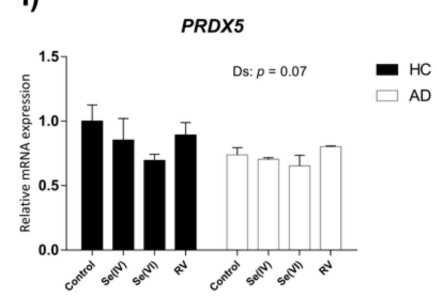

Figure 3. Relative expression of genes involved in oxidative stress in AD and HC lymphoblast cell lines treated with selenite (Se (IV)), selenate (Se (VI)), and resveratrol (RV). Gene expression analysis by real-time PCR from lymphoblast mRNA using TaqMan Fluorescein amidite (FAM)-labeled specific probes and normalized with the mean of both housekeeping genes: phosphoglycerate kinase 1 (PGK1) and beta-2-microglobulin (B2M). (a) Catalase (CAT); (b) copper chaperone for SOD1 (CCS); (c) alpha galactosidase (GLA); (d) glutathione peroxidase 1 (GPX1); (e) glutathione peroxidase 4 (GPX4); (f) glutathione reductase (GSR); (g) glutathione S-transferase zeta 1 (GSTZ1); (h) nuclear factor (erythroid-derived 2)-like 2 (NEF2L2); (i) peroxiredoxin 5 (PRDX5); (j) superoxide dismutase 2 (SOD2); (k) thioredoxin interacting protein (TXNIP). $P$-values for two-way ANOVA analysis are indicated at the top or right area of the graph. Tr: treatment effect; Ds: disease effect. $P$-values of Tukey's post hoc tests for each group (relative to control treatment) are indicated in the graphs as: $+p<0.1,{ }^{*} p<0.05$, ${ }^{* *} p<0.01,{ }^{* * * *} p<0.0001$. Values are mean \pm SEM of two to four independent experiments with $\mathrm{n}=2$ /experiment on two different cell lines per group. HC and AD stand for healthy control and Alzheimer's disease, respectively.

\subsection{Transcriptional Changes in Age-Related Genes Induced by Se (IV), Se (VI), and RV in HC and AD LCLs}

Se and RV are reported to have a beneficial effect on lifespan, telomere length, DNA damage, inflammation, senile plaque formation, hyperphosphorylation of tau, and other processes associated with aging and AD. Although the exact mechanisms of action remain unclear, some authors have observed changes in aging-related genes as a consequence of RV and Se treatments in different 
models $[45,46,58]$. To further explore the mechanisms by which these compounds exert potential therapeutic effects in $\mathrm{AD}$, we treated $\mathrm{HC}$ and $\mathrm{AD}$ lymphoblasts with either the vehicle alone or the previously tested concentrations of $10 \mu \mathrm{M}$ Se (IV), $200 \mu \mathrm{M}$ Se (VI), and $50 \mu \mathrm{M} \mathrm{RV}$. We then measured the mRNA levels of a battery of genes involved in age-related processes or AD pathology (Table 2, Supplementary Table S1).

Two-way ANOVA analysis revealed that SIRT1 and SIRT3 were upregulated by treatment (Table 2, Figure 4e). Post hoc analysis, however, only yielded significance for RV treatment using Fisher's LSD test, which does not correct for multiple comparisons (SIRT1: HC control vs. HC RV, $p<0.05$; SIRT3: HC or AD control vs. HC or AD RV, $p<0.05)$. Notably, both caspase 1 (CASP1) and vacuolar protein sorting 13 homolog C (VPS13C) were increased in AD compared to HC lymphoblasts according to two-way ANOVA analysis (Table 2, Figure 4a,k). No interactions between treatment and disease were detected for any of the genes studied.

Here we found upregulation of the pro-survival and neuroprotection sirtuin genes SIRT1 and SIRT3 by RV in both LCLs. However, the higher levels of the pro-apoptotic CASP1 gene and proteostasis-related VPS13C gene in AD LCLs were not reversed by either RV or Se treatment. 
Table 2. Two-way ANOVA analysis of relative expression of age-related genes in AD and HC lymphoblasts treated with selenite (Se (IV)), selenate (Se (VI)), and resveratrol $(\mathrm{RV})$.

\begin{tabular}{|c|c|c|c|c|c|c|c|c|c|c|c|c|}
\hline \multirow{2}{*}{ Gene Name } & \multirow{2}{*}{ Association with Aging } & \multirow{2}{*}{ Ref } & \multirow{2}{*}{$\begin{array}{l}\text { Gene } \\
\text { Symbol }\end{array}$} & \multicolumn{3}{|c|}{ Interaction } & \multicolumn{3}{|c|}{ Treatment Effect } & \multicolumn{3}{|c|}{ Disease Effect } \\
\hline & & & & F & $\begin{array}{l}\text { (DFn, } \\
\text { DFd) }\end{array}$ & $p$-Value & F & $\begin{array}{l}\text { (DFn, } \\
\text { DFd) }\end{array}$ & $p$-Value & F & $\begin{array}{l}\text { (DFn, } \\
\text { DFd) }\end{array}$ & $p$-Value \\
\hline Caspase 1 & $\begin{array}{l}\text { CASP1 is an inflammatory/apoptotic caspase involved in age-related cognitive } \\
\text { impairment. }\end{array}$ & [59] & CASP1 & 0.02562 & $(3,11)$ & 0.9941 & 0.04521 & $(3,11)$ & 0.9865 & 8.679 & $(1,11)$ & 0.0133 \\
\hline $\begin{array}{l}\text { E1A binding } \\
\text { protein p300 }\end{array}$ & $\begin{array}{l}\text { EP300 is a transcriptional coactivator that mediates many transcriptional } \\
\text { events including DNA repair. It also acts as a histone acetyltransferase to } \\
\text { regulate transcription through chromatin structural changes. EP300 activity is } \\
\text { attenuated in ageing mice. }\end{array}$ & [60] & EP300 & 0.06183 & $(3,11)$ & 0.9789 & 0.5095 & $(3,11)$ & 0.6838 & 1.135 & $(1,11)$ & 0.3096 \\
\hline $\begin{array}{l}\text { Forkhead box } \\
\quad \text { O1 }\end{array}$ & $\begin{array}{l}\text { FOXO proteins represent a subfamily of transcription factors that act as key } \\
\text { regulators of longevity downstream of insulin and insulin-like growth factor } \\
\text { signaling. They are involved in stress resistance, metabolism, cell cycle arrest, } \\
\text { and apoptosis. }\end{array}$ & [61] & FOXO1 & 0.05955 & $(3,11)$ & 0.9800 & 0.1451 & $(3,11)$ & 0.9307 & 1.252 & $(1,11)$ & 0.2870 \\
\hline Sirtuin 1 & \multirow{3}{*}{$\begin{array}{l}\text { Sirtuins are nicotinamide adenine dinucleotide (NAD)-dependent protein } \\
\text { deacetylases involved in oxidative stress, metabolism, inflammation, and other } \\
\text { aging-related cellular processes. Lifestyle factors, including physical activity } \\
\text { and diet, can influence healthspan via modifying the level of sirtuins. }\end{array}$} & \multirow{3}{*}[62]{} & SIRT1 & 0.5235 & $(3,11)$ & 0.675 & 4.022 & $(3,11)$ & 0.0371 & 0.7906 & $(1,11)$ & 0.3930 \\
\hline Sirtuin 3 & & & SIRT3 & 0.07819 & $(3,11)$ & 0.9705 & 7.481 & $(3,11)$ & 0.0053 & 1.058 & $(1,11)$ & 0.3258 \\
\hline Sirtuin 6 & & & SIRT6 & 0.2715 & $(3,11)$ & 0.8447 & 0.5264 & $(3,11)$ & 0.6732 & 0.04267 & $(1,11)$ & 0.5270 \\
\hline $\begin{array}{l}\text { Synaptosome } \\
\text { associated } \\
\text { protein } 23\end{array}$ & $\begin{array}{l}\text { SNAP23 regulates synaptic vesicle trafficking and fusion, and it is increased } \\
\text { with aging and in AD patients. }\end{array}$ & [63] & SNAP23 & 0.04866 & $(3,11)$ & 0.985 & 1.97 & $(3,11)$ & 0.1771 & 0.7959 & $(1,11)$ & 0.3914 \\
\hline $\begin{array}{l}\text { Transcription } \\
\text { factor B1, } \\
\text { mitochondrial }\end{array}$ & $\begin{array}{l}\text { TFB1M is a dimethyltransferase involved in mitochondrial transcription. It is } \\
\text { thought that this protein plays a role on the loss of mitochondrial function } \\
\text { encountered in numerous disease states and the aging process. }\end{array}$ & [64] & TFB1M & 0.7357 & $(3,11)$ & 0.5523 & 0.3503 & $(3,11)$ & 0.7898 & 2.256 & $(1,11)$ & 0.1612 \\
\hline $\begin{array}{c}\text { TERF1 } \\
\text { interacting } \\
\text { nuclear factor } 2\end{array}$ & $\begin{array}{l}\text { TINF2 is a component of the shelterin complex (telosome) that is involved in } \\
\text { the regulation of telomere length and protection. }\end{array}$ & [65] & TINF2 & 0.1374 & $(3,11)$ & 0.9356 & 0.31 & $(3,11)$ & 0.8178 & 1.166 & $(1,11)$ & 0.3033 \\
\hline $\begin{array}{l}\text { Toll interacting } \\
\text { protein }\end{array}$ & $\begin{array}{l}\text { TOLLIP is an adaptor molecule within the toll-like receptor (TLR) signaling } \\
\text { pathway. It is involved in autophagy and clearance of protein aggregates and it } \\
\text { is decreased in AD models. }\end{array}$ & [66] & TOLLIP & 22.59 & $(3,11)$ & 0.200 & 46.49 & $(3,11)$ & 0.0516 & 0.009 & $(1,11)$ & 0.962 \\
\hline $\begin{array}{l}\text { Vacuolar } \\
\text { protein sorting } \\
13 \text { homolog C }\end{array}$ & $\begin{array}{l}\text { VPS13A is a lipid transport protein. Its dysfunction in the nervous system is } \\
\text { described to shorten life span and trigger age-associated neurodegeneration in } \\
\text { animal models. Mutations in the human VPS13 genes are responsible for } \\
\text { neurodevelopmental and neurodegenerative disorders. }\end{array}$ & [67] & VPS13C & 0.2332 & $(3,11)$ & 0.8713 & 1.327 & $(3,11)$ & 0.3153 & 9.003 & $(1,11)$ & 0.0121 \\
\hline
\end{tabular}

$p$-values $<0.05$ were considered statistically significant. DF stands for degrees of freedom. Bold and italic values correspond to statistically significant $p$-values and $p$-values $<0.1$, respectively. 
a)

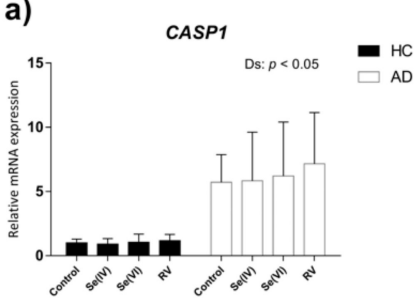

d)

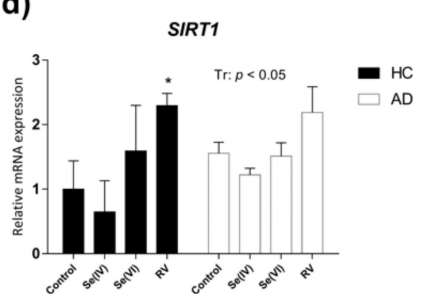

g)

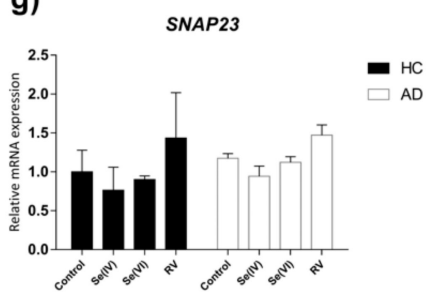

j)

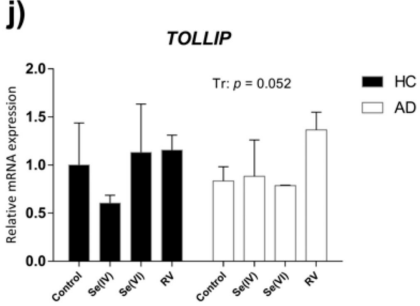

b)

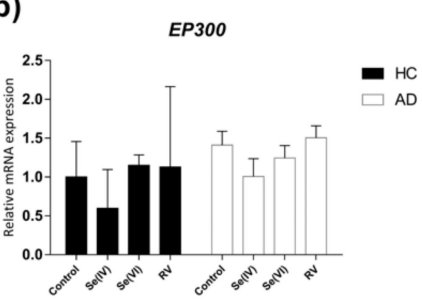

e)

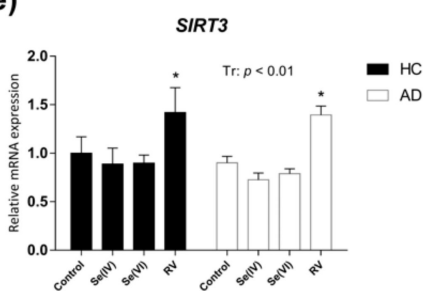

h)

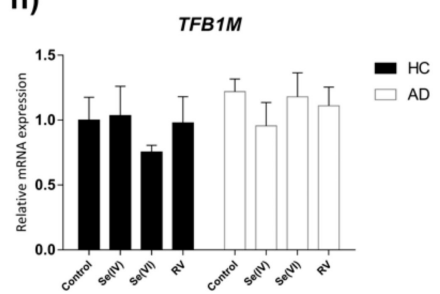

k)

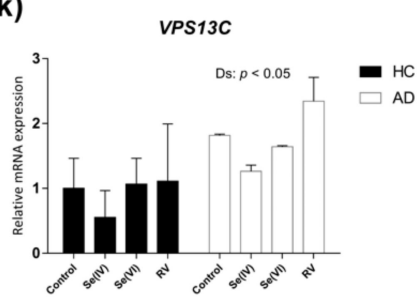

c)

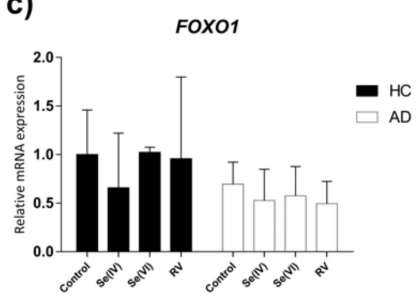

f)

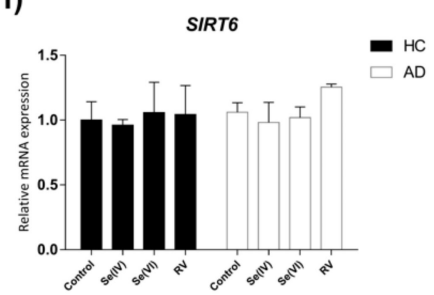

i)

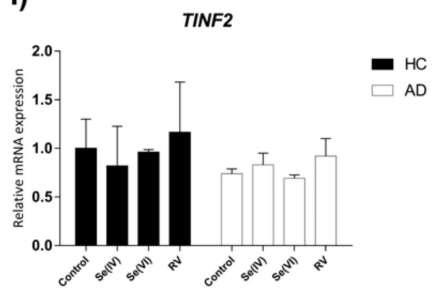

Figure 4. Relative expression of age-related genes in AD and HC lymphoblast cell lines treated with selenite (Se (IV)), selenate (Se (VI)), and resveratrol (RV). Gene expression analysis by real-time PCR from lymphoblast mRNA using TaqMan FAM-labeled specific probes and normalized with the mean of both housekeeping genes: phosphoglycerate kinase 1 (PGK1) and beta-2-microglobulin (B2M).

(a) Caspase 1 (CASP1); (b) E1A binding protein p300 (EP300); (c) forkhead box O1 (FOXO1); (d) sirtuin 1 (SIRT1); (e) sirtuin 3 (SIRT3); (f) sirtuin 6 (SIRT6); (g) synaptosome associated protein 23 (SNAP23); (h) transcription factor B1, mitochondrial (TFB1M); (i) TERF1-interacting nuclear factor 2 (TINF2); (j) vacuolar protein sorting 13 homolog C (VPS13A). $P$-values for two-way ANOVA are indicated at the top or on the right. Tr: treatment effect; Ds: disease effect. $P$-values of Fischer's LSD post hoc test for each group (relative to control treatment) are indicated as: ${ }^{*} p<0.05$. Values are mean \pm SEM of two to four independent experiments with $n=2$ /experiment on two different cell lines per group. HC and AD stand for healthy control and Alzheimer's disease, respectively.

\subsection{Characterization of Transcriptional Changes Induced by RV at Different Concentrations on Selected} Candidate Genes in HC and AD LCLs

RV showed higher potency in upregulating gene expression of key protective genes than Se compounds in our experimental conditions. Therefore, to better explore the protective mechanisms of RV against aging and AD in this human LCL model, we performed a concentration-response study of RV. To this end, AD and HC lymphoblasts were treated for $18 \mathrm{~h}$ with the vehicle alone or RV at a concentration of $10 \mu \mathrm{M}, 20 \mu \mathrm{M}$, and $50 \mu \mathrm{M}$. We measured mRNA levels of those genes that previously showed a significant change for Tr or Ds effect (Figures 3 and 4). 
Two-way ANOVA analysis indicated a general upregulation of CAT, CCS, GSTZ1, NFE2L2, SIRT1, SIRT3, SOD2, TXNIP, and VPS13C in both AD and HC LCLs due to the treatment with RV (Table 3, Figure $5 b-j)$. However, according to Tukey's post hoc tests, it was the highest concentration of RV that promoted significant increases in the expression of these genes (CCS: HC $0 \mu \mathrm{M}$ vs. HC $50 \mu \mathrm{M} \mathrm{RV}$, $p<0.05$, AD $0 \mu \mathrm{M}$ vs. AD $50 \mu \mathrm{M}$ RV, $p<0.05$; GSTZ1: HC $0 \mu \mathrm{M}$ vs. HC $50 \mu \mathrm{M}$ RV, $p<0.001$, AD $0 \mu \mathrm{M}$ vs. AD $50 \mu \mathrm{M}$ RV, $p<0.0001$; SIRT1: HC $0 \mu \mathrm{M}$ vs. HC $50 \mu \mathrm{M}$ RV, $p<0.0001$, AD $0 \mu \mathrm{M}$ vs. AD $50 \mu \mathrm{M}$ RV, $p<0.0001$; SIRT3: HC $0 \mu \mathrm{M}$ vs. HC $50 \mu \mathrm{M}$ RV, $p<0.001$, AD $0 \mu \mathrm{M}$ vs. AD $50 \mu \mathrm{M}$ RV, $p<0.0001$; SOD2: HC $0 \mu \mathrm{M}$ vs. HC $50 \mu \mathrm{M}$ RV, $p<0.01$, AD $0 \mu \mathrm{M}$ vs. AD $50 \mu \mathrm{M} \mathrm{RV,} p<0.0001$; TXNIP: HC $0 \mu \mathrm{M}$ vs. HC $50 \mu \mathrm{M}$ RV, $p<0.001$, AD $0 \mu \mathrm{M}$ vs. AD $50 \mu \mathrm{M}$ RV, $p<0.001$; VPS13C: HC $0 \mu \mathrm{M}$ vs. HC $50 \mu \mathrm{M}$ $\mathrm{RV}, p<0.1, \mathrm{AD} 0 \mu \mathrm{M}$ vs. AD $50 \mu \mathrm{M} \mathrm{RV}, p<0.05$ ) (Figure 5). In the case of NFEL2L and CAT, this upregulation was only present in the $\mathrm{HC}$ and in $\mathrm{AD}$ cell lines, respectively (CAT: AD $0 \mu \mathrm{M}$ vs. AD $50 \mu \mathrm{M}$ RV, $p<0.05$; NFEL2L: HC $0 \mu \mathrm{M}$ vs. HC $50 \mu \mathrm{M}$ RV, $p<0.1$ ) (Figure 5b,g).

AD lymphoblasts exhibited general upregulation of CASP1 and SOD2 and a downregulation of CCS compared to HC, according to two-way ANOVA (Table 3, Figure 5a,c,h).

These results generally confirmed the upregulation of antioxidant and anti-aging genes by RV in both HC and AD LCLs. However, the increased expression of CASP1 in AD was not modified.

Table 3. Two-way ANOVA analysis of relative expression of candidate genes involved in aging and oxidative stress in AD and HC lymphoblasts treated with different concentrations of resveratrol (RV).

\begin{tabular}{|c|c|c|c|c|c|c|c|c|c|}
\hline \multirow{2}{*}{ Gene Symbol } & \multicolumn{3}{|c|}{ Interaction } & \multicolumn{3}{|c|}{ Treatment Effect } & \multicolumn{3}{|c|}{ Disease Effect } \\
\hline & $\mathbf{F}$ & (DFn, DFd) & $P$ Value & F & (DFn, DFd) & $p$-Value & $\mathbf{F}$ & (DFn, DFd) & $p$-Value \\
\hline CASP1 & 0.01959 & $(3,84)$ & 0.9962 & 0.2699 & $(3,84)$ & 0.8469 & 73.8 & $(1,84)$ & $<0.0001$ \\
\hline$C A T$ & 0.1504 & $(3,84)$ & 0.9292 & 8.508 & $(3,84)$ & $<0.0001$ & 0.6411 & $(1,84)$ & 0.4256 \\
\hline $\mathrm{CCS}$ & 0.2515 & $(3,84)$ & 0.8601 & 10.34 & $(3,84)$ & $<0.0001$ & 7.605 & $(1,84)$ & 0.0071 \\
\hline GSTZ1 & 0.2779 & $(3,84)$ & 0.8412 & 26.42 & $(3,84)$ & $<0.0001$ & 0.1917 & $(1,84)$ & 0.6626 \\
\hline NFE2L2 & 0.03848 & $(3,84)$ & 0.9898 & 7.453 & $(3,84)$ & $<0.0001$ & 2.202 & $(1,84)$ & 0.1416 \\
\hline SIRT1 & 0.4004 & $(3,84)$ & 0.7531 & 27.86 & $(3,84)$ & $<0.0001$ & 0.8486 & $(1,84)$ & 0.3596 \\
\hline SIRT3 & 0.06445 & $(3,84)$ & 0.9785 & 23.87 & $(3,84)$ & $<0.0001$ & 0.2658 & $(1,84)$ & 0.6075 \\
\hline SOD2 & 0.2123 & $(3,82)$ & 0.8876 & 20 & $(3,82)$ & $<0.0001$ & 0.4858 & $(1,82)$ & 0.0132 \\
\hline TXNIP & 0.002772 & $(3,84)$ & 0.9998 & 21.07 & $(3,84)$ & $<0.0001$ & 0.5962 & $(1,84)$ & 0.4422 \\
\hline VPS13C & 0.452 & $(3,84)$ & 0.7165 & 8.398 & $(3,84)$ & $<0.0001$ & 0.01005 & $(1,84)$ & 0.9204 \\
\hline
\end{tabular}

$p$-values $<0.05$ were considered statistically significant. DF stands for degrees of freedom. Bold and italic values correspond to statistically significant $p$-values and $p$-values $<0.1$, respectively. 
a)

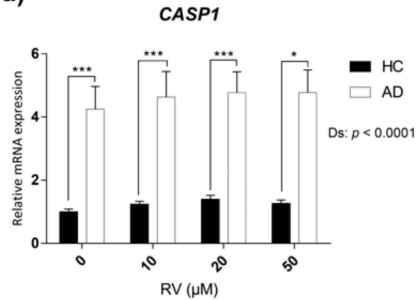

d)

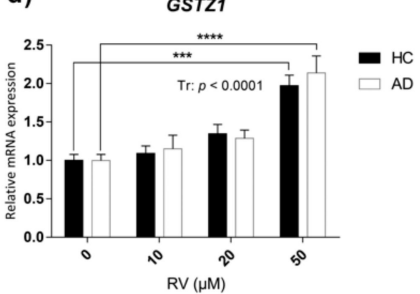

g)
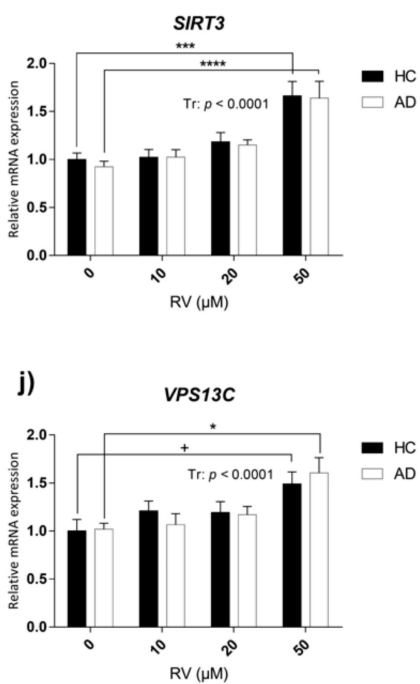

b)

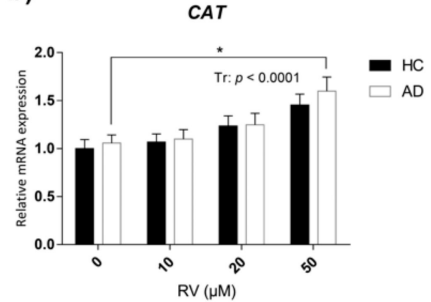

e)

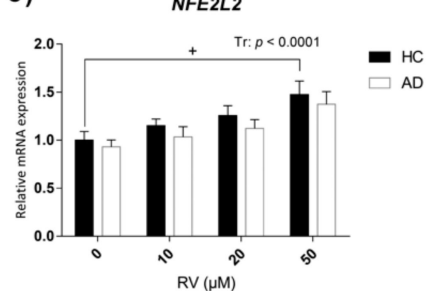

h)

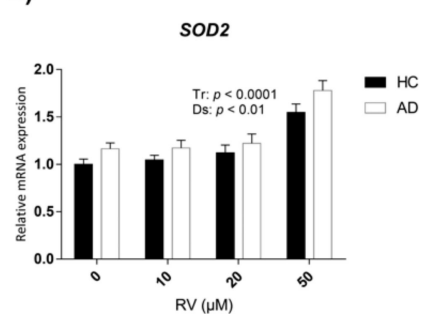

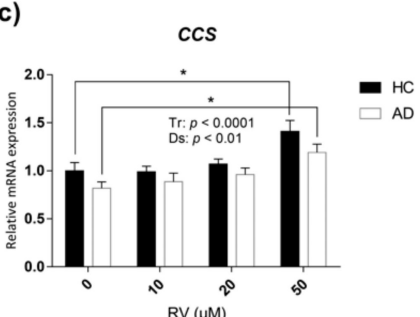

c)

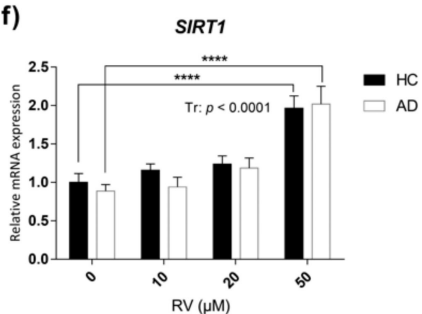

i)

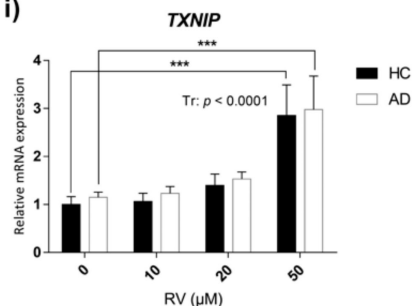

Figure 5. Relative expression of candidate genes involved in oxidative stress and aging in AD and HC lymphoblast cell lines treated with different concentrations of resveratrol (RV). Gene expression analysis by real-time PCR from lymphoblast mRNA using TaqMan FAM-labeled specific probes and normalized with the mean of both housekeeping genes: phosphoglycerate kinase 1 (PGK1) and beta-2-microglobulin (B2M). (a) Caspase 1 (CASP1); (b) catalase (CAT); (c) copper chaperone for SOD1 (CCS); (d) glutathione S-transferase zeta 1 (GSTZ1); (e) nuclear factor (erythroid-derived 2)-like 2 (NFE2L2); (f) sirtuin 1 (SIRT1); (g) sirtuin 3 (SIRT3); (h) superoxide dismutase 2 (SOD2); (i) thioredoxin-interacting protein (TXNIP); (j) vacuolar protein sorting 13 homolog C (VPS13C). P-values for two-way ANOVA analysis are indicated at the top or on the right. Tr: treatment effect; Ds: disease effect. $P$-values for Tukey's post hoc tests are indicated as: $+p<0.1,^{*} p<0.05,{ }^{* * *} p<0.001,{ }^{* * * *} p<0.0001$. Values are mean \pm SEM of seven to thirteen independent experiments with $n=2$ /experiment on two different cell lines per group. $\mathrm{HC}$ and $\mathrm{AD}$ stand for healthy control and Alzheimer's disease, respectively.

\section{Discussion}

In this study, we used LCLs derived from lymphocytes of AD patients and age-matched HCs to investigate the potential protective effects of RV and both Se (IV) and Se (VI) on ROS levels, generated at basal conditions and after an oxidative insult. We also studied the potential mechanisms of action involving modulation of antioxidant and anti-aging genes. 
AD LCLs showed lower antioxidant defenses than HC LCLs, with higher ROS levels in response to different concentrations of oxidizing agents $\left(\mathrm{H}_{2} \mathrm{O}_{2}\right.$ and $\left.\mathrm{FeSO}_{4}\right)$. The increased oxidative stress of AD LCLs is consistent with observations in many studies using fresh lymphocytes from AD patients $[4,68]$, suggesting that the immortalized AD lymphocytes are a valuable model to test protective strategies. Furthermore, cellular level oxidative stress might be associated with pathology severity in the donor. In a cell model of familial AD by expression of PSEN1 mutations in fibroblasts, we have previously seen higher basal and $\mathrm{H}_{2} \mathrm{O}_{2}$-induced ROS in the more aggressive mutations than in those causing a milder AD phenotype [69]. Here we used LCLs obtained at a moderate stage of sporadic AD and they showed distinct characteristics of oxidative stress. We may speculate that they show intermediate levels of AD-associated oxidative stress and are a sensitive model to test responses to interventions.

Interestingly, in the absence of oxidative insults, RV decreased ROS levels in both AD and HC LCLs. Given that oxidative stress is recognized as a risk factor for developing AD, this finding supports the potential preventive and therapeutic effects of this component by reducing the ROS burden not only in AD patients but also in healthy and at-risk populations. Consistent with this, it has been reported that RV can prevent the deleterious effects triggered by oxidative stress in neuronal cells and brain tissue of experimental AD models [70,71]. Likewise, under oxidizing conditions RV triggered a global protective response towards ROS in both AD and HC LCLs. Although the specific mode of action of RV needs further characterization, its antioxidant properties may contribute to the potent neuroprotective effects reported in AD mouse models [14-16], and to the promising effects reported in clinical trials with AD patients $[19,20,72]$.

The Se compounds we used confirmed the antioxidant properties of this element in LCLs, although both Se (IV) and Se (VI) only exerted antioxidant effects in AD cell lines under $\mathrm{H}_{2} \mathrm{O}_{2}$ or $\mathrm{FeSO}_{4}$ treatment. This suggests that, compared to RV, Se (IV) and Se (VI) need a stronger oxidizing insult and higher basal levels of ROS to exert beneficial effects at the particular concentrations studied and time of exposure. In fact, whereas Se levels are decreased in AD patients [25,26], a recent study has shown that Se status is not associated with cognitive performance in a healthy population [73]. Similarly, no preventive AD effects have been reported for Se supplementation in a long-term supplementation trial [74]. Future studies of Se therapeutic properties would clarify whether there is increased protection under greater oxidant/antioxidant imbalance.

Regarding our transcriptional experiments, Se (IV) and Se (VI) did not significantly regulate any of the genes studied. Interestingly, we observed a general upregulation of the following genes caused by RV: CAT, CCS, GSTZ1, NFE2L2, SIRT1, SIRT3, SOD2, and TXNIP. Treatment with the highest concentration of RV (50 $\mathrm{MM})$ consistently upregulated CAT, CCS, GSTZ1, NFE2L2, SIRT1, SIRT3, SOD2, TXNIP, and VPS13C in both AD and HC LCLs (there was a global RV effect for all these genes). Notably, NFE2L2 (also known as NRF2) is a transcription factor involved in the activation of genes with antioxidant response elements (AREs) such as SOD1 and many members of the glutathione S-transferase family [75], to counteract endogenously or exogenously generated oxidative stress. It also upregulates the expression of the histone deacetylases SIRT1 [76,77] and SIRT3 [78,79], according to several studies. The upregulation of NFE2L2 could, therefore, be responsible for the upregulation of GSTZ1, CCS (a chaperone involved in the activation of SOD1), and both SIRT1 and SIRT3. Similarly, SIRT1 can enhance the activity of the NFE212/ARE pathway according to some authors, thus establishing a positive feedback $[77,80,81]$. These findings are consistent with previous studies of brain ischemia, Parkinson's disease, and other pathological conditions showing that treatment with RV activates the NFE212/ARE pathway [82,83]. Furthermore, RV has been proven to activate SIRT1 through the metabolic sensor AMPK, as indicated above, which is consistent with findings in animal studies [15]. Similarly, the increase in CAT expression is consistent with some animal and human studies showing an increase in both activity and expression of this enzyme as a consequence of RV treatment [84] or SIRT1 overexpression [85]. SIRT1 is known to deacetylate SOD1 and promote its activity by facilitating its association with copper chaperone for SOD1 (CCS); therefore, the upregulation of both genes as a consequence of RV treatment may further contribute to ROS elimination by increasing SOD1 activity [86]. 
Interestingly, the gene in the sirtuin family SIRT3 is a known key enzyme for the functionality of mitochondria and its decrease is linked to neurodegeneration such as AD [87]. SOD2 is another mitochondrial enzyme that was upregulated by RV. Consistently, a previous study reported that SOD2 expression was induced by RV-dependent activation of the PI3K/Akt and GSK-3 $\beta / \beta$-catenin signaling pathways [88]. RV upregulation of SIRT3 and SOD2 would improve mitochondrial metabolism and energy efficiency, leading to decreased mitochondrial oxidative stress. In some cases, either $\mathrm{HC}$ or AD LCLs showed greater responsiveness to the upregulation of specific genes. For instance, the increase of NEF2L2 by RV was significant in HC LCLs, whereas in the case of CAT the upregulation was significant for AD LCLs. This suggests that some genes could have a different response to RV treatment according to the cellular environment. For example, it is possible that $C A T$ expression is sensitive to RV in a context of higher oxidative stress, and that NEF2L2 constitutes a target of RV when used as a preventive approach or early treatment (i.e., when there is a low to moderate burden of ROS). Meanwhile, TXNIP is considered an intracellular amplifier of oxidative stress, since it is a negative regulator of the thioredoxin system; a major cellular thiol-reducing and antioxidant system. According to several authors, RV inhibits TXNIP expression [89]. Unexpectedly, we observed slight upregulation of this gene by RV, which is inconsistent with previous findings and could be counterproductive in the context of AD. Special attention should be paid to this issue in future studies. Finally, genetic studies have implicated loss-of-function mutations in the human VPS13 gene in neurodegenerative disorders by causing defects in membrane lipid homeostasis $[67,90]$. The increase in this gene by RV might help prevent aging-associated lipid imbalances [91].

Regarding basal transcriptional differences between HC and AD LCLs, we observed that AD lymphoblasts exhibited general upregulation of CASP1 and SOD2 and downregulation of CCS. Consistently, CASP1 is activated in AD brains and overexpressed in monocytes from AD patients, and it is in fact considered a therapeutic target against age-dependent cognitive deficits and AD [92,93]. Elevated antioxidant enzyme levels have been reported before in AD patients [94], and the upregulation of SOD2 might indicate compensatory upregulation of mitochondrial antioxidant defenses in response to oxidative stress in AD LCLs. Interestingly, a downregulation of CCS has been reported in several AD models, which diminishes SOD1 activity and increases the expression of the enzyme $\beta$-secretase 1 involved in the amyloidogenic processing of the amyloid precursor protein (APP) [94-97]. We found that RV treatment upregulated CCS expression levels, thus reaching and surpassing those of HC LCLs under basal conditions.

Overall, this study confirms a derangement of oxidative defenses in lymphocytes from AD patients, indicating lower resilience to oxidative injuries and age-related oxidative stress, and supports $\mathrm{RV}$ as a more powerful compound, with more consistent and robust effects regarding antioxidant and transcriptional outcomes, than Se (IV) or Se (VI) under our experimental conditions. In particular, modulation of gene expression of important anti-aging (SIRT1, SIRT3, VPS13C) and antioxidant (CAT, CCS, GSTZ1, NFE2L2, SOD2) genes by RV seems to be partly contributing to its mechanism of action. The fact that protective mechanisms of RV are activated in cells from both healthy and diseased $\mathrm{AD}$ donors is in agreement with the activation of protective mechanisms against aberrant proteostasis in both wild-type and AD transgenic mice after chronic treatment with RV [15]. In that last study, we found that RV mechanisms yielded a strong neuroprotection against memory loss and $\mathrm{AD}$ pathology in transgenic mice and cognitive enhancement in wild-type mice. Here, the activation of anti-aging and antioxidant genes in our peripheral cell models further confirms that RV may be a potent protective agent and an inducer of resilience against aging and AD. Thus, in accordance with our findings and those of previous reports, RV should be studied further and considered a valuable nutraceutical candidate for early therapies aiming to prevent or delay the onset and progression of $A D$ clinical symptoms.

Moreover, our findings reinforce the value of LCLs as a feasible model for understanding the protective mechanisms of nutraceuticals with antioxidant properties (such as RV) against the cumulative burden of oxidative stress and other cell alterations in AD. 
Supplementary Materials: The following are available online at http://www.mdpi.com/2072-6643/11/8/1764/s1, Table S1: List of primers and probe sets used for real time RT-PCR analysis.

Author Contributions: Conceptualization, M.C.-T., P.K. and C.S. (Coral Sanfeliu); methodology, M.C.-T., C.A. and C.S. (Coral Sanfeliu); formal analysis, M.C.-T., J.S. and M.A.-P.; investigation, J.S., and M.A.; resources, C.A., Á.M.-R., C.S. (Cristina Suñol). and C.S. (Coral Sanfeliu); writing-original draft preparation, M.C.-T.; writing-review and editing, C.A., M.P., Á.M.-R., C.S. (Cristina Suñol), P.K. and C.S. (Coral Sanfeliu); visualization M.C.-T.; supervision, C.S. (Coral Sanfeliu); project administration, C.S. (Coral Sanfeliu); funding acquisition, C.S. (Coral Sanfeliu).

Funding: This research was funded by Spanish MINECO and FEDER, grant number SAF2016-75508; Catalan Autonomous Government AGAUR, grant number 2017-SGR-106; and the CERCA Programme/Generalitat de Catalunya.

Acknowledgments: We thank Mari Carmen Duarte, Andrés Jurado, and Alaó Gatius for preliminary experiments and technical contributions. We thank Barbara Rita Cardoso for helpful advice and discussion on Se treatment.

Conflicts of Interest: The authors declare no conflicts of interest.

\section{References}

1. Bondi, M.W.; Edmonds, E.C.; Salmon, D.P. Alzheimer's Disease: Past, Present, and Future. J. Int. Neuropsychol. Soc. JINS 2017, 23, 818-831. [CrossRef]

2. Dubois, B.; Hampel, H.; Feldman, H.H.; Scheltens, P.; Aisen, P.; Andrieu, S.; Bakardjian, H.; Benali, H.; Bertram, L.; Blennow, K.; et al. Preclinical Alzheimer's disease: Definition, natural history, and diagnostic criteria. Alzheimers Dement. J. Alzheimer's Assoc. 2016, 12, 292-323. [CrossRef]

3. Jack, C.R.; Bennett, D.A.; Blennow, K.; Carrillo, M.C.; Dunn, B.; Haeberlein, S.B.; Holtzman, D.M.; Jagust, W.; Jessen, F.; Karlawish, J.; et al. NIA-AA Research Framework: Toward a biological definition of Alzheimer's disease. Alzheimer's Dement. J. Alzheimers Assoc. 2018, 14, 535-562. [CrossRef]

4. Wojsiat, J.; Zoltowska, K.M.; Laskowska-Kaszub, K.; Wojda, U. Oxidant/Antioxidant Imbalance in Alzheimer's Disease: Therapeutic and Diagnostic Prospects. Oxid. Med. Cell. Longev. 2018, 2018, 16. [CrossRef]

5. Sutherland, G.T.; Chami, B.; Youssef, P.; Witting, P.K. Oxidative stress in Alzheimer's disease: Primary villain or physiological by-product? Redox Rep. Commun. Free Radic. Res. 2013, 18, 134-141. [CrossRef]

6. García-Mesa, Y.; Colie, S.; Corpas, R.; Cristòfol, R.; Comellas, F.; Nebreda, A.R.; Giménez-Llort, L.; Sanfeliu, C. Oxidative Stress Is a Central Target for Physical Exercise Neuroprotection Against Pathological Brain Aging. J. Gerontol. A. Biol. Sci. Med. Sci. 2016, 71, 40-49. [CrossRef]

7. García-Matas, S.; Paul, R.K.; Molina-Martínez, P.; Palacios, H.; Gutierrez, V.M.; Corpas, R.; Pallas, M.; Cristòfol, R.; de Cabo, R.; Sanfeliu, C. In vitro caloric restriction induces protective genes and functional rejuvenation in senescent SAMP8 astrocytes. Aging Cell 2015, 14, 334-344. [CrossRef]

8. Sebastià, J.; Pertusa, M.; Vílchez, D.; Planas, A.M.; Verbeek, R.; Rodríguez-Farré, E.; Cristòfol, R.; Sanfeliu, C. Carboxyl-terminal fragment of amyloid precursor protein and hydrogen peroxide induce neuronal cell death through different pathways. J. Neural Transm. Vienna Austria 1996 2006, 113, 1837-1845. [CrossRef]

9. Kelsey, N.A.; Wilkins, H.M.; Linseman, D.A. Nutraceutical Antioxidants as Novel Neuroprotective Agents. Molecules 2010, 15, 7792-7814. [CrossRef]

10. Evans, H.M.; Howe, P.R.C.; Wong, R.H.X. Effects of Resveratrol on Cognitive Performance, Mood and Cerebrovascular Function in Post-Menopausal Women; A 14-Week Randomised Placebo-Controlled Intervention Trial. Nutrients 2017, 9, 27. [CrossRef]

11. Hubbard, B.P.; Sinclair, D.A. Small molecule SIRT1 activators for the treatment of aging and age-related diseases. Trends Pharmacol. Sci. 2014, 35, 146-154. [CrossRef]

12. Price, N.L.; Gomes, A.P.; Ling, A.J.Y.; Duarte, F.V.; Martin-Montalvo, A.; North, B.J.; Agarwal, B.; Ye, L.; Ramadori, G.; Teodoro, J.S.; et al. SIRT1 is required for AMPK activation and the beneficial effects of resveratrol on mitochondrial function. Cell Metab. 2012, 15, 675-690. [CrossRef]

13. Park, S.-J.; Ahmad, F.; Philp, A.; Baar, K.; Williams, T.; Luo, H.; Ke, H.; Rehmann, H.; Taussig, R.; Brown, A.L.; et al. Resveratrol ameliorates aging-related metabolic phenotypes by inhibiting cAMP phosphodiesterases. Cell 2012, 148, 421-433. [CrossRef]

14. Kim, D.; Nguyen, M.D.; Dobbin, M.M.; Fischer, A.; Sananbenesi, F.; Rodgers, J.T.; Delalle, I.; Baur, J.A.; Sui, G.; Armour, S.M.; et al. SIRT1 deacetylase protects against neurodegeneration in models for Alzheimer's disease and amyotrophic lateral sclerosis. EMBO J. 2007, 26, 3169-3179. [CrossRef] 
15. Corpas, R.; Griñán-Ferré, C.; Rodríguez-Farré, E.; Pallàs, M.; Sanfeliu, C. Resveratrol Induces Brain Resilience against Alzheimer Neurodegeneration through Proteostasis Enhancement. Mol. Neurobiol. 2019, 56, 1502-1516. [CrossRef]

16. Porquet, D.; Griñán-Ferré, C.; Ferrer, I.; Camins, A.; Sanfeliu, C.; Del Valle, J.; Pallàs, M. Neuroprotective role of trans-resveratrol in a murine model of familial Alzheimer's disease. J. Alzheimer's Dis. JAD 2014, 42, 1209-1220. [CrossRef]

17. Porquet, D.; Casadesús, G.; Bayod, S.; Vicente, A.; Canudas, A.M.; Vilaplana, J.; Pelegrí, C.; Sanfeliu, C.; Camins, A.; Pallàs, M.; et al. Dietary resveratrol prevents Alzheimer's markers and increases life span in SAMP8. Age Dordr. Neth. 2013, 35, 1851-1865. [CrossRef]

18. Cristòfol, R.; Porquet, D.; Corpas, R.; Coto-Montes, A.; Serret, J.; Camins, A.; Pallàs, M.; Sanfeliu, C. Neurons from senescence-accelerated SAMP8 mice are protected against frailty by the sirtuin 1 promoting agents melatonin and resveratrol. J. Pineal Res. 2012, 52, 271-281. [CrossRef]

19. Turner, R.S.; Thomas, R.G.; Craft, S.; van Dyck, C.H.; Mintzer, J.; Reynolds, B.A.; Brewer, J.B.; Rissman, R.A.; Raman, R.; Aisen, P.S.; et al. A randomized, double-blind, placebo-controlled trial of resveratrol for Alzheimer disease. Neurology 2015, 85, 1383-1391. [CrossRef]

20. Moussa, C.; Hebron, M.; Huang, X.; Ahn, J.; Rissman, R.A.; Aisen, P.S.; Turner, R.S. Resveratrol regulates neuro-inflammation and induces adaptive immunity in Alzheimer's disease. J. Neuroinflamm. 2017, $14,1$. [CrossRef]

21. Fairweather-Tait, S.J.; Bao, Y.; Broadley, M.R.; Collings, R.; Ford, D.; Hesketh, J.E.; Hurst, R. Selenium in human health and disease. Antioxid. Redox Signal. 2011, 14, 1337-1383. [CrossRef]

22. Zheng, L.; Zhu, H.-Z.; Wang, B.-T.; Zhao, Q.-H.; Du, X.-B.; Zheng, Y.; Jiang, L.; Ni, J.-Z.; Zhang, Y.; Liu, Q. Sodium selenate regulates the brain ionome in a transgenic mouse model of Alzheimer's disease. Sci. Rep. 2016, 6, 39290. [CrossRef]

23. Haratake, M.; Yoshida, S.; Mandai, M.; Fuchigami, T.; Nakayama, M. Elevated amyloid- $\beta$ plaque deposition in dietary selenium-deficient Tg2576 transgenic mice. Met. Integr. Biomet. Sci. 2013, 5, 479-483. [CrossRef]

24. Van Eersel, J.; Ke, Y.D.; Liu, X.; Delerue, F.; Kril, J.J.; Götz, J.; Ittner, L.M. Sodium selenate mitigates tau pathology, neurodegeneration, and functional deficits in Alzheimer's disease models. Proc. Natl. Acad. Sci. USA 2010, 107, 13888-13893. [CrossRef]

25. Varikasuvu, S.R.; Prasad, V.S.; Kothapalli, J.; Manne, M. Brain Selenium in Alzheimer's Disease (BRAIN SEAD Study): A Systematic Review and Meta-Analysis. Biol. Trace Elem. Res. 2019, 189, 361-369. [CrossRef]

26. Cardoso, B.R.; Hare, D.J.; Bush, A.I.; Li, Q.-X.; Fowler, C.J.; Masters, C.L.; Martins, R.N.; Ganio, K.; Lothian, A.; Mukherjee, S.; et al. Selenium Levels in Serum, Red Blood Cells, and Cerebrospinal Fluid of Alzheimer's Disease Patients: A Report from the Australian Imaging, Biomarker \& Lifestyle Flagship Study of Ageing (AIBL). J. Alzheimer's Dis. JAD 2017, 57, 183-193.

27. Wang, J.; Gu, B.J.; Masters, C.L.; Wang, Y.J. A systemic view of Alzheimer disease-Insights from amyloid- $\beta$ metabolism beyond the brain. Nat. Rev. Neurol. 2017, 13, 612-623. [CrossRef]

28. Wojda, U. Alzheimer's disease lymphocytes: potential for biomarkers? Biomark. Med. 2016, 10, 1-4. [CrossRef]

29. Hui-Yuen, J.; McAllister, S.; Koganti, S.; Hill, E.; Bhaduri-McIntosh, S. Establishment of Epstein-Barr virus growth-transformed lymphoblastoid cell lines. J. Vis. Exp. JoVE 2011, 57, e3321. [CrossRef]

30. De las Cuevas, N.; Urcelay, E.; Hermida, O.G.; Saíz-Diaz, R.A.; Bermejo, F.; Ayuso, M.S.; Martín-Requero, A. $\mathrm{Ca} 2+/$ calmodulin-dependent modulation of cell cycle elements $\mathrm{pRb}$ and $\mathrm{p} 27 \mathrm{kip} 1$ involved in the enhanced proliferation of lymphoblasts from patients with Alzheimer dementia. Neurobiol. Dis. 2003, 13, 254-263. [CrossRef]

31. Del Cerro, P.; Alquézar, C.; Bartolomé, F.; González-Naranjo, P.; Pérez, C.; Carro, E.; Páez, J.A.; Campillo, N.E.; Martín-Requero, Á. Activation of the Cannabinoid Type 2 Receptor by a Novel Indazole Derivative Normalizes the Survival Pattern of Lymphoblasts from Patients with Late-Onset Alzheimer's Disease. CNS Drugs 2018, 32, 579-591. [CrossRef]

32. Esteras, N.; Alquézar, C.; Bermejo-Pareja, F.; Bialopiotrowicz, E.; Wojda, U.; Martín-Requero, A. Downregulation of extracellular signal-regulated kinase 1/2 activity by calmodulin KII modulates p21Cip1 levels and survival of immortalized lymphocytes from Alzheimer's disease patients. Neurobiol. Aging 2013, 34, 1090-1100. [CrossRef] 
33. Lahiri, D.K.; Xu, Y.; Klaunig, J.; Baiyewu, O.; Ogunniyi, A.; Hall, K.; Hendrie, H.; Sahota, A. Effect of oxidative stress on DNA damage and beta-amyloid precursor proteins in lymphoblastoid cell lines from a Nigerian population. Ann. N. Y. Acad. Sci. 1999, 893, 331-336. [CrossRef]

34. Johnston, J.A.; Lannfelt, L.; Wiehager, B.; O'Neill, C.; Cowburn, R.F. Amyloid precursor protein heat shock response in lymphoblastoid cell lines bearing presenilin-1 mutations. Biochim. Biophys. Acta 1997, 1362, 183-192. [CrossRef]

35. Matsumoto, A.; Fujiwara, Y. Abnormal and deficient processing of beta-amyloid precursor protein in familial Alzheimer's disease lymphoblastoid cells. Biochem. Biophys. Res. Commun. 1991, 175, 361-365. [CrossRef]

36. Matsumoto, A.; Fujiwara, Y. Aberrant proteolysis of the beta-amyloid precursor protein in familial Alzheimer's disease lymphoblastoid cells. Eur. J. Biochem. 1993, 217, 21-27. [CrossRef]

37. Abe, K.; St George-Hyslop, P.H.; Tanzi, R.E.; Kogure, K. Induction of amyloid precursor protein mRNA after heat shock in cultured human lymphoblastoid cells. Neurosci. Lett. 1991, 125, 169-171. [CrossRef]

38. Ounanian, A.; Guilbert, B.; Seigneurin, J.M. Characteristics of Epstein-Barr virus transformed B cell lines from patients with Alzheimer's disease and age-matched controls. Mech. Ageing Dev. 1992, 63, 105-116. [CrossRef]

39. Bryant, E.M.; Bird, T.D.; Ogburn, C.E.; Traylor, G.H.; Lampe, T.H.; Martin, G.M. Lack of detectable radiation hypersensitivity in lymphoblastoid cells from multiple pedigrees of familial Alzheimer disease. Alzheimer Dis. Assoc. Disord. 1993, 7, 88-97. [CrossRef]

40. Kalyanaraman, B.; Darley-Usmar, V.; Davies, K.J.A.; Dennery, P.A.; Forman, H.J.; Grisham, M.B.; Mann, G.E.; Moore, K.; Roberts, L.J.; Ischiropoulos, H. Measuring reactive oxygen and nitrogen species with fluorescent probes: challenges and limitations. Free Radic. Biol. Med. 2012, 52, 1-6. [CrossRef]

41. Spyrou, G.; Björnstedt, M.; Skog, S.; Holmgren, A. Selenite and selenate inhibit human lymphocyte growth via different mechanisms. Cancer Res. 1996, 56, 4407-4412.

42. Pedram, S.; Mohammadirad, A.; Rezvanfar, M.A.; Navaei-Nigjeh, M.; Baeeri, M.; Abdollahi, M. On The Protection by The Combination of $\mathrm{CeO}_{2}$ Nanoparticles and Sodium Selenite on Human Lymphocytes against Chlorpyrifos-Induced Apoptosis In Vitro. Cell J. 2015, 17, 361-371.

43. Lee, L.-C.; Weng, Y.-T.; Wu, Y.-R.; Soong, B.-W.; Tseng, Y.-C.; Chen, C.-M.; Lee-Chen, G.-J. Downregulation of proteins involved in the endoplasmic reticulum stress response and Nrf2-ARE signaling in lymphoblastoid cells of spinocerebellar ataxia type 17. J. Neural Transm. Vienna Austria 1996 2014, 121, 601-610. [CrossRef]

44. Hosein Poor Feyzi, A.A.; Farshdousti Hagh, M.; Ebadi, T.; Shams Asanjan, K.; Movasagpoor Akbari, A.; Talebi, M.; Emadi, B. The effect of resveratrol on the expression of MDR1 gene in leukemic lymphoblast's of acute lymphoblastic leukemia patients. Casp. J. Intern. Med. 2015, 6, 113-115.

45. Gambini, J.; Inglés, M.; Olaso, G.; Lopez-Grueso, R.; Bonet-Costa, V.; Gimeno-Mallench, L.; Mas-Bargues, C.; Abdelaziz, K.M.; Gomez-Cabrera, M.C.; Vina, J.; et al. Properties of Resveratrol: In Vitro and In Vivo Studies about Metabolism, Bioavailability, and Biological Effects in Animal Models and Humans. Oxid. Med. Cell. Longev. 2015, 2015. [CrossRef]

46. Zoidis, E.; Seremelis, I.; Kontopoulos, N.; Danezis, G.P. Selenium-Dependent Antioxidant Enzymes: Actions and Properties of Selenoproteins. Antioxidants 2018, 7, 66. [CrossRef]

47. Al-Abrash, A.S.; Al-Quobaili, F.A.; Al-Akhras, G.N. Catalase evaluation in different human diseases associated with oxidative stress. Saudi Med. J. 2000, 21, 826-830.

48. Brown, N.M.; Torres, A.S.; Doan, P.E.; O'Halloran, T.V. Oxygen and the copper chaperone CCS regulate posttranslational activation of $\mathrm{Cu}, \mathrm{Zn}$ superoxide dismutase. Proc. Natl. Acad. Sci. USA. 2004, 101, 5518-5523. [CrossRef]

49. Shen, J.-S.; Meng, X.-L.; Moore, D.F.; Quirk, J.M.; Shayman, J.A.; Schiffmann, R.; Kaneski, C.R. Globotriaosylceramide induces oxidative stress and up-regulates cell adhesion molecule expression in Fabry disease endothelial cells. Mol. Genet. Metab. 2008, 95, 163-168. [CrossRef]

50. Mohammedi, K.; Patente, T.A.; Bellili-Muñoz, N.; Driss, F.; Le Nagard, H.; Fumeron, F.; Roussel, R.; Hadjadj, S.; Corrêa-Giannella, M.L.; Marre, M.; et al. Glutathione peroxidase-1 gene (GPX1) variants, oxidative stress and risk of kidney complications in people with type 1 diabetes. Metabolism 2016, 65, 12-19. [CrossRef]

51. Seiler, A.; Schneider, M.; Förster, H.; Roth, S.; Wirth, E.K.; Culmsee, C.; Plesnila, N.; Kremmer, E.; Rådmark, O.; Wurst, W.; et al. Glutathione Peroxidase 4 Senses and Translates Oxidative Stress into 12/15-Lipoxygenase Dependent- and AIF-Mediated Cell Death. Cell Metab. 2008, 8, 237-248. [CrossRef] 
52. Cheng, S.B.; Liu, H.T.; Chen, S.Y.; Lin, P.T.; Lai, C.Y.; Huang, Y.C. Changes of Oxidative Stress, Glutathione, and Its Dependent Antioxidant Enzyme Activities in Patients with Hepatocellular Carcinoma before and after Tumor Resection. PLoS ONE 2017, 12, e0170016. [CrossRef]

53. Blackburn, A.C.; Matthaei, K.I.; Lim, C.; Taylor, M.C.; Cappello, J.Y.; Hayes, J.D.; Anders, M.W.; Board, P.G. Deficiency of glutathione transferase zeta causes oxidative stress and activation of antioxidant response pathways. Mol. Pharmacol. 2006, 69, 650-657. [CrossRef]

54. Wen, J.J.; Porter, C.; Garg, N.J. Inhibition of NFE2L2-Antioxidant Response Element Pathway by Mitochondrial Reactive Oxygen Species Contributes to Development of Cardiomyopathy and Left Ventricular Dysfunction in Chagas Disease. Antioxid. Redox Signal. 2017, 27, 550-566. [CrossRef]

55. Yuan, J.; Murrell, G.A.C.; Trickett, A.; Landtmeters, M.; Knoops, B.; Wang, M.-X. Overexpression of antioxidant enzyme peroxiredoxin 5 protects human tendon cells against apoptosis and loss of cellular function during oxidative stress. Biochim. Biophys. Acta 2004, 1693, 37-45. [CrossRef]

56. Velarde, M.C.; Flynn, J.M.; Day, N.U.; Melov, S.; Campisi, J. Mitochondrial oxidative stress caused by Sod2 deficiency promotes cellular senescence and aging phenotypes in the skin. Aging 2012, 4, 3-12. [CrossRef]

57. Oberacker, T.; Bajorat, J.; Ziola, S.; Schroeder, A.; Röth, D.; Kastl, L.; Edgar, B.A.; Wagner, W.; Gülow, K.; Krammer, P.H. Enhanced expression of thioredoxin-interacting-protein regulates oxidative DNA damage and aging. Febs Lett. 2018, 592, 2297-2307. [CrossRef]

58. Cai, Z.; Zhang, J.; Li, H. Selenium, aging and aging-related diseases. Aging Clin. Exp. Res. 2018, 31, $1035-1047$. [CrossRef]

59. Gemma, C.; Bickford, P.C. Interleukin-1beta and caspase-1: players in the regulation of age-related cognitive dysfunction. Rev. Neurosci. 2007, 18, 137-148. [CrossRef]

60. Bedford, D.C.; Brindle, P.K. Is histone acetylation the most important physiological function for CBP and p300? Aging 2012, 4, 247-255. [CrossRef]

61. Martins, R.; Lithgow, G.J.; Link, W. Long live FOXO: Unraveling the role of FOXO proteins in aging and longevity. Aging Cell 2016, 15, 196-207. [CrossRef]

62. Grabowska, W.; Sikora, E.; Bielak-Zmijewska, A. Sirtuins, a promising target in slowing down the ageing process. Biogerontology 2017, 18, 447-476. [CrossRef]

63. Berchtold, N.C.; Coleman, P.D.; Cribbs, D.H.; Rogers, J.; Gillen, D.L.; Cotman, C.W. Synaptic genes are extensively downregulated across multiple brain regions in normal human aging and Alzheimer's disease. Neurobiol. Aging 2013, 34, 1653-1661. [CrossRef]

64. McCulloch, V.; Shadel, G.S. Human Mitochondrial Transcription Factor B1 Interacts with the C-Terminal Activation Region of h-mtTFA and Stimulates Transcription Independently of Its RNA Methyltransferase Activity. Mol. Cell. Biol. 2003, 23, 5816-5824. [CrossRef]

65. Savage, S.A.; Giri, N.; Baerlocher, G.M.; Orr, N.; Lansdorp, P.M.; Alter, B.P. TINF2, a component of the shelterin telomere protection complex, is mutated in dyskeratosis congenita. Am. J. Hum. Genet. 2008, 82, 501-509. [CrossRef]

66. Chen, K.; Yuan, R.; Geng, S.; Zhang, Y.; Ran, T.; Kowalski, E.; Liu, J.; Li, L. Toll-interacting protein deficiency promotes neurodegeneration via impeding autophagy completion in high-fat diet-fed ApoE ${ }^{-/-}$mouse model. Brain Behav. Immun. 2017, 59, 200-210. [CrossRef]

67. Kumar, N.; Leonzino, M.; Hancock-Cerutti, W.; Horenkamp, F.A.; Li, P.; Lees, J.A.; Wheeler, H.; Reinisch, K.M.; De Camilli, P. VPS13A and VPS13C are lipid transport proteins differentially localized at ER contact sites. J. Cell Biol. 2018, 217, 3625-3639. [CrossRef]

68. Wojsiat, J.; Prandelli, C.; Laskowska-Kaszub, K.; Martín-Requero, A.; Wojda, U. Oxidative Stress and Aberrant Cell Cycle in Alzheimer's Disease Lymphocytes: Diagnostic Prospects. J. Alzheimer's Dis. JAD 2015, 46, 329-350. [CrossRef]

69. Sarroca, S.; Molina-Martínez, P.; Aresté, C.; Etzrodt, M.; García de Frutos, P.; Gasa, R.; Antonell, A.; Molinuevo, J.L.; Sánchez-Valle, R.; Saura, C.A.; et al. Preservation of cell-survival mechanisms by the presenilin-1 K239N mutation may cause its milder clinical phenotype. Neurobiol. Aging 2016, 46, 169-179. [CrossRef]

70. Wang, H.; Jiang, T.; Li, W.; Gao, N.; Zhang, T. Resveratrol attenuates oxidative damage through activating mitophagy in an in vitro model of Alzheimer's disease. Toxicol. Lett. 2018, 282, 100-108. [CrossRef] 
71. Dong, Y.T.; Cao, K.; Tan, L.C.; Wang, X.L.; Qi, X.L.; Xiao, Y.; Guan, Z.Z. Stimulation of SIRT1 Attenuates the Level of Oxidative Stress in the Brains of APP/PS1 Double Transgenic Mice and in Primary Neurons Exposed to Oligomers of the Amyloid- $\beta$ Peptide. J. Alzheimer's Dis. JAD 2018, 63, 283-301. [CrossRef]

72. Ramírez-Garza, S.L.; Laveriano-Santos, E.P.; Marhuenda-Muñoz, M.; Storniolo, C.E.; Tresserra-Rimbau, A.; Vallverdú-Queralt, A.; Lamuela-Raventós, R.M. Health Effects of Resveratrol: Results from Human Intervention Trials. Nutrients 2018, 10, 1892. [CrossRef]

73. Cardoso, B.R.; Szymlek-Gay, E.A.; Roberts, B.R.; Formica, M.; Gianoudis, J.; O'Connell, S.; Nowson, C.A.; Daly, R.M. Selenium Status Is Not Associated with Cognitive Performance: A Cross-Sectional Study in 154 Older Australian Adults. Nutrients 2018, 10, 1847. [CrossRef]

74. Kryscio, R.J.; Abner, E.L.; Caban-Holt, A.; Lovell, M.; Goodman, P.; Darke, A.K.; Yee, M.; Crowley, J.; Schmitt, F.A. Association of Antioxidant Supplement Use and Dementia in the Prevention of Alzheimer's Disease by Vitamin E and Selenium Trial (PREADViSE). JAMA Neurol. 2017, 74, 567-573. [CrossRef]

75. Nguyen, T.; Nioi, P.; Pickett, C.B. The Nrf2-antioxidant response element signaling pathway and its activation by oxidative stress. J. Biol. Chem. 2009, 284, 13291-13295. [CrossRef]

76. Han, J.; Liu, X.; Li, Y.; Zhang, J.; Yu, H. Sirt1/Nrf2 signalling pathway prevents cognitive impairment in diabetic rats through anti-oxidative stress induced by miRNA-23b-3p expression. Mol. Med. Rep. 2018, 17, 8414-8422. [CrossRef]

77. Huang, K.; Gao, X.; Wei, W. The crosstalk between Sirt1 and Keap1/Nrf2/ARE anti-oxidative pathway forms a positive feedback loop to inhibit FN and TGF- $\beta 1$ expressions in rat glomerular mesangial cells. Exp. Cell Res. 2017, 361, 63-72. [CrossRef]

78. Gao, J.; Liu, S.; Xu, F.; Liu, Y.; Lv, C.; Deng, Y.; Shi, J.; Gong, Q. Trilobatin Protects Against Oxidative Injury in Neuronal PC12 Cells Through Regulating Mitochondrial ROS Homeostasis Mediated by AMPK/Nrf2/Sirt3 Signaling Pathway. Front. Mol. Neurosci. 2018, 11, 267. [CrossRef]

79. Satterstrom, F.K.; Swindell, W.R.; Laurent, G.; Vyas, S.; Bulyk, M.L.; Haigis, M.C. Nuclear respiratory factor 2 induces SIRT3 expression. Aging Cell 2015, 14, 818-825. [CrossRef]

80. Da Cunha, M.D.S.B.; Arruda, S.F. Tucum-do-Cerrado (Bactris setosa Mart.) May Promote Anti-Aging Effect by Upregulating SIRT1-Nrf2 Pathway and Attenuating Oxidative Stress and Inflammation. Nutrients 2017, 9, 1243. [CrossRef]

81. Chai, D.; Zhang, L.; Xi, S.; Cheng, Y.; Jiang, H.; Hu, R. Nrf2 Activation Induced by Sirt1 Ameliorates Acute Lung Injury After Intestinal Ischemia/Reperfusion Through NOX4-Mediated Gene Regulation. Cell. Physiol. Biochem. Int. J. Exp. Cell. Physiol. Biochem. Pharmacol. 2018, 46, 781-792. [CrossRef]

82. Sun, Y.; Yang, T.; Leak, R.K.; Chen, J.; Zhang, F. Preventive and protective roles of dietary Nrf2 activators against central nervous system diseases. CNS Neurol. Disord. Drug Targets 2017, 16, 326-338. [CrossRef]

83. Kim, E.N.; Lim, J.H.; Kim, M.Y.; Ban, T.H.; Jang, I.-A.; Yoon, H.E.; Park, C.W.; Chang, Y.S.; Choi, B.S. Resveratrol, an Nrf2 activator, ameliorates aging-related progressive renal injury. Aging 2018, 10, 83-99. [CrossRef]

84. Gomes, B.A.Q.; Silva, J.P.B.; Romeiro, C.F.R.; dos Santos, S.M.; Rodrigues, C.A.; Gonçalves, P.R.; Sakai, J.T.; Mendes, P.F.S.; Varela, E.L.P.; Monteiro, M.C. Neuroprotective Mechanisms of Resveratrol in Alzheimer's Disease: Role of SIRT1. Available online: https://www.hindawi.com/journals/omcl/2018/8152373/ (accessed on 6 May 2019).

85. Cheng, Y.; Takeuchi, H.; Sonobe, Y.; Jin, S.; Wang, Y.; Horiuchi, H.; Parajuli, B.; Kawanokuchi, J.; Mizuno, T.; Suzumura, A. Sirtuin 1 attenuates oxidative stress via upregulation of superoxide dismutase 2 and catalase in astrocytes. J. Neuroimmunol. 2014, 269, 38-43. [CrossRef]

86. Lin, C.; Zeng, H.; Lu, J.; Xie, Z.; Sun, W.; Luo, C.; Ding, J.; Yuan, S.; Geng, M.; Huang, M. Acetylation at lysine 71 inactivates superoxide dismutase 1 and sensitizes cancer cells to genotoxic agents. Oncotarget 2015, 6, 20578-20591. [CrossRef]

87. Lee, J.; Kim, Y.; Liu, T.; Hwang, Y.J.; Hyeon, S.J.; Im, H.; Lee, K.; Alvarez, V.E.; McKee, A.C.; Um, S.J.; et al. SIRT3 deregulation is linked to mitochondrial dysfunction in Alzheimer's disease. Aging Cell 2018, 17, e12679. [CrossRef]

88. Fukui, M.; Choi, H.J.; Zhu, B.T. Mechanism for the Protective Effect of Resveratrol against Oxidative Stress-Induced Neuronal Death. Free Radic. Biol. Med. 2010, 49, 800-813. [CrossRef] 
89. Liang, Y.; Che, X.; Zhao, Q.; Darwazeh, R.; Zhang, H.; Jiang, D.; Zhao, J.; Xiang, X.; Qin, W.; Liu, L.; et al. Thioredoxin-interacting protein mediates mitochondrion-dependent apoptosis in early brain injury after subarachnoid hemorrhage. Mol. Cell. Biochem. 2019, 450, 149-158. [CrossRef]

90. Meda, S.A.; Narayanan, B.; Liu, J.; Perrone-Bizzozero, N.I.; Stevens, M.C.; Calhoun, V.D.; Glahn, D.C.; Shen, L.; Risacher, S.L.; Saykin, A.J.; et al. A large scale multivariate parallel ICA method reveals novel imaging-genetic relationships for Alzheimer's disease in the ADNI cohort. NeuroImage 2012, 60, 1608-1621. [CrossRef]

91. Shamim, A.; Mahmood, T.; Ahsan, F.; Kumar, A.; Bagga, P. Lipids: An insight into the neurodegenerative disorders. Clin. Nutr. Exp. 2018, 20, 1-19. [CrossRef]

92. Saresella, M.; La Rosa, F.; Piancone, F.; Zoppis, M.; Marventano, I.; Calabrese, E.; Rainone, V.; Nemni, R.; Mancuso, R.; Clerici, M. The NLRP3 and NLRP1 inflammasomes are activated in Alzheimer's disease. Mol. Neurodegener. 2016, 11, 23. [CrossRef]

93. Flores, J.; Noël, A.; Foveau, B.; Lynham, J.; Lecrux, C.; LeBlanc, A.C. Caspase-1 inhibition alleviates cognitive impairment and neuropathology in an Alzheimer's disease mouse model. Nat. Commun. 2018, 9, 3916. [CrossRef]

94. Massaad, C.A. Neuronal and Vascular Oxidative Stress in Alzheimer's Disease. Curr. Neuropharmacol. 2011, 9, 662-673. [CrossRef]

95. Angeletti, B.; Waldron, K.J.; Freeman, K.B.; Bawagan, H.; Hussain, I.; Miller, C.C.J.; Lau, K.-F.; Tennant, M.E.; Dennison, C.; Robinson, N.J.; et al. BACE1 cytoplasmic domain interacts with the copper chaperone for superoxide dismutase-1 and binds copper. J. Biol. Chem. 2005, 280, 17930-17937. [CrossRef]

96. Gray, E.H.; De Vos, K.J.; Dingwall, C.; Perkinton, M.S.; Miller, C.C.J. Deficiency of the Copper Chaperone for Superoxide Dismutase Increases Amyloid- $\beta$ Production. J. Alzheimer's Dis. JAD 2010, 21, 1101-1105. [CrossRef]

97. Greenough, M.A.; Volitakis, I.; Li, Q.-X.; Laughton, K.; Evin, G.; Ho, M.; Dalziel, A.H.; Camakaris, J.; Bush, A.I. Presenilins promote the cellular uptake of copper and zinc and maintain copper chaperone of SOD1-dependent copper/zinc superoxide dismutase activity. J. Biol. Chem. 2011, 286, 9776-9786. [CrossRef]

(C) 2019 by the authors. Licensee MDPI, Basel, Switzerland. This article is an open access article distributed under the terms and conditions of the Creative Commons Attribution (CC BY) license (http://creativecommons.org/licenses/by/4.0/). 